\title{
Padrones de población e historiografía sobre la configuración socio-racial hispanoamericana del siglo XVIII
}

\author{
Sergio Paolo Solano D. \\ Universidad de Cartagena \\ ssolanod@unicartagena.edu.co
}

Recibido: Noviembre de 2013

Aprobado: Febrero de 2014

Resumen: En este artículo analizo una parte de la historiografía latinoamericana que ha estudiado las relaciones entre la construcción de los censos de población, las categorías socio-raciales que contienen y la configuración social colonial del siglo XVIII, el poder y los juegos conflictivos entre las identidades adscritas y las asumidas. Me interesa mostrar la creciente problematización que ha adquirido el estudio de estos aspectos, pasando de un largo periodo de lectura ingenua de los censos y de las categorías socio-raciales, a ver como se construían en un diálogo conflictivo entre intereses del poder, perspectivas de los empadronadores e intereses de los empadronados. También me interesa mostrar el reciente desarrollo de una historiografía que empieza a llamar la atención sobre ciertas categorías políticas del periodo colonial tardío y como estas complejizaban lo socio-racial.

Palabras claves: historiografía, censos de población, categorías socio-raciales

\section{Population patterns and historiography on the Spanish- American socio-racial configuration of the XVIII century}

\begin{abstract}
In this article is analyzed the historiography concerning the socio- racial categories and surveys of Latin American colonies in the late eighteenth century. I want to show the increasing problematic that has acquired both issues, from a long period of naive reading of the census and socio- racial categories they contain, look how were built a dialogue between conflicting interests of power, registers perspectives and interests of a register . I also want to show the development of a historiography that begins to draw attention to certain political categories of the late colonial period and how those categories complex the socio-racial issue.
\end{abstract}

Key words: historiography, population censuses, socio-racial categories.

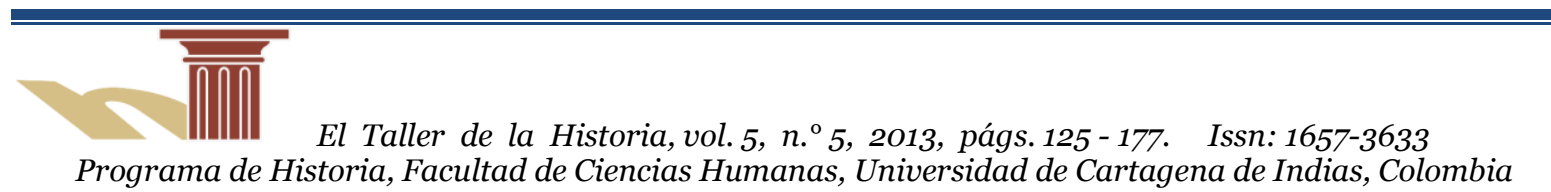




\section{Presentación}

Uno de los tema de la historia colonial hispanoamericana que más ha suscitado discusiones es el de la configuración social de los distintos virreinatos y capitanías durante el siglo XVIII, como también los significados de las categorías socio-raciales que se empleaban y las distintas variaciones en las esferas provinciales y locales. ${ }^{1}$ De una etapa inicial que gravitó en torno a lo que se consideraba como los criterios objetivos para definir a los grupos (clases como estructuras acabadas, esencialismos raciales y étnicos), la historiografía reciente ha colocado el tema en el plano de las distintas situaciones en que se desenvolvían las relaciones de los individuos y grupos, y las discusiones se han centrado en el análisis de los discursos y de las prácticas sociales de los sujetos y sectores subalternos, y sus relaciones con el poder.

Entre esos debates uno de los más conocidos se desarrolló desde finales de los años de 1970 y durante el decenio siguiente sobre el modelo de análisis a aplicar para estudiar las características de la sociedad de la Nueva España del siglo XVIII. Por un lado estaban quienes perseveraban en la tesis de la primacía de la estratificación socio-racial; por otra parte se encontraban quienes en vía contraria defendían la aplicación de un modelo que subrayaba la pérdida de importancia de lo racial y la primacía que había logrado la estratificación en clases sociales debido al crecimiento económico y del mestizaje en ese virreinato. Según los defensores de este punto de vista, los factores económicos, demográficos y las múltiples categorías socio-raciales ocasionaron una no correspondencia entre el color y la riqueza, distribuyéndose esta entre los diversos sectores de sociedad, y perdiendo los blancos la concentración de ese factor de poder. Consideran que para finales de ese siglo era la condición de clase la que tenía un protagonismo fundamental en la sociedad novohispana. ${ }^{2}$

\footnotetext{
${ }^{1}$ Carmen Bernand, "Mestizos, mulatos y ladinos en Hispanoamérica: un enfoque antropológico de un proceso histórico", en Miguel León Portilla (ed.), Motivos de la antropología americanista: Indagaciones en la diferencia, México D. F., Fondo de Cultura Económica, 2001, pp.105-133.

${ }^{2}$ Una buena síntesis sobre el estado del debate sobre el tema de raza, clase y diversidad de mestizajes en Nueva España puede leerse en Patrick J. Carroll, "El debate académico sobre los significados sociales entre clase y raza en el México del siglo XVIII", en María E. Velásquez (coord.), Debates históricos contemporáneos: africanos y afrodescendientes en México y Centroamérica, México D. F., Centro de Estudios Mexicanos y Centroamericanos/Instituto Nacional de Antropología e Histo-
} 
Esas discusiones originaron interpretaciones intermedias que le dan validez a la combinación de ambos modelos. ${ }^{3}$ Y por último, sectores de historiadores creyeron que el debate estaba mal planteado y que lo que determinaba la ubicación de las personas en el orden social era la "calidad", concepto de uso extendido durante la Colonia y que integraba una diversidad de factores tales como la "raza", la posición económica, la ocupación, el estilo de vida, los lazos de parentescos, las redes sociales a que se perteneciera, el sitio de vivienda y otros elementos. ${ }^{4}$ Aunque este último recurso metodológico ha puesto el debate en un plano mucho más productivo si se le mira por el lado de la importancia de tener en cuenta diversos elementos, se le achaca el dejar en una situación indeterminada la jerarquía entre esos factores en el establecimiento del rango social de las personas. ${ }^{5}$

Sin que esas discusiones estén concluidas, hoy se acepta tanto la existencia de distintas formas de clasificación de acuerdo a los contextos en los que estuvieran insertas las personas, como también que en unas situaciones los diversos factores que determinaban la calidad podían operan en bloque, y en otras situaciones se privilegiaban uno o unos sobre otros aspectos. En fin, al centrarse las reflexiones sobre las dinámicas sociales que podían reafirmar algunas persistencias del factor socio-racial, en los aspectos que expresaban un posible tránsito de unas sociedades de estamentos y status a las de clases, o en el conjunto de factores que determinaba la calidad social de las personas, esas discusiones han mostrado algunas de las tantas aristas que posee el tema de las configuraciones de las sociedades coloniales. De hecho estas controversias llevaron a desmontar la idea de la existencia de un sistema rígido de castas que impedía cualquier forma de movilidad social, lo que reducía los diversos mestizajes a procesos biológicos y les negaba cualquier importancia social y política en la dinámica social.

ria/Institut de Recherche pour le Développement/Universidad Nacional Autónoma de México, 2011, pp.111-142. También ver a María E. Velásquez, "Introducción”, en Debates históricos contemporáneos: africanos y afrodescendientes en México y Centroamérica, pp.13-31.

${ }^{3}$ Juan C. Garavaglia y Juan C. Grosso, "Identidad, identidades: una visión desde la América hispana siglos XVIII-XIX”, en Quaderns n. ${ }^{\circ}$ 25, Barcelona, Universidad Autónoma de Barcelona, 2009, p.26; Jorge Conde, Buscando la nación. Ciudadanía, clase y tensión racial en el Caribe colombiano, 1821-1855, Medellín, Universidad del Atlántico/La Carreta Eds., 2009, p.18.

${ }^{4}$ Pilar Gonzalbo, La familia y el nuevo orden colonial, México D. F., El Colegio de México, 1998, pp.13-14, 130.

${ }^{5}$ P. J. Carroll, "El debate académico sobre los significados sociales entre clase y raza en el México del siglo XVIII", pp.111-142. 
En parte el desmonte de esa idea ha venido de la mano con el desarrollo de nuevos modelos de análisis que colocaron las identidades en unos planos relacionales y situacionales, preguntándose por las relaciones entre el poder, las relaciones sociales y las características de los discursos y de las escrituras coloniales. Quienes han elaborado y desarrollado una agenda investigativa ligada a estas preocupaciones se han visto obligados a reorientar varios aspectos de las formas como tradicionalmente se ha asumido el estudio de la sociedad colonial. Por una parte le han otorgado prioridad al estudio de los fenómenos culturales e ideológicos, en especial a cómo las dialécticas entre el poder, los discursos, los sujetos y las prácticas sociales logran producir, instrumentalizar y modificar una realidad social. Para avanzar en esta dirección analizan las relaciones entre los sujetos sociales y las estructuras, privilegiando una reducción de la escala de análisis a través de los estudios de casos. ${ }^{6}$ También han extendido el periodo estudiado a los siglos XVI y XVII con el propósito de tener unas perspectivas más completas sobre la evolución de las categorías socio-raciales durante todo el periodo colonial. Esto porque durante mucho tiempo las investigaciones sobre la Colonia temprana se circunscribieron al tema de los contactos iniciales entre españoles, indios y negros, y los historiadores sobre el siglo XVIII creyeron tener una comprensión acabada de esas categorías, y sus supuestos significados los extendieron a los siglos que les precedieron.

Aquellas investigaciones han tomado tres direcciones. Por un lado están los historiadores que enfatizan en el estudio de los hiatos que se fueron estableciendo entre los discursos de poder que insistían en mantener un sistema de castas, la normatividad jurídica que consagraba derechos, deberes y exclusiones acorde con ese régimen y la vida social que ponía en entredicho esas clasificaciones. De forma creciente se empieza a reconocer la existencia de inconsistencias en los vínculos entre las categorías político-jurídicas que definían la ubicación de las personas y grupos en el orden socio-racial, y la potencial puesta en escena de diversas identidades en la vida social. Esto implica reconocer que los límites entre las diversas castas registradas en los archivos y en las pinturas de Nueva España y de Lima, se fueron haciendo difíciles de establecer, y que para los blancos con limpieza de sangre esa flexibilidad constituía una amenazaba para sus privilegios. El color ya no

\footnotetext{
${ }^{6}$ Un seguimiento a estos debates en Verena Stolcke, “A propósito de fronteras y mestizajes”, en Monserrat Ventura (ed.), Fronteras de mestizajes. Sistemas de clasificación social en Europa, América y África, Barcelona, Universidad Autónoma de Barcelona, 2010, pp.19-29.
} 
podía ser la única barrera. Antes por el contrario; en muchas situaciones perdía la condición de dique que separaba, y terminaba desdibujándose en la vida social. ${ }^{7}$

Por otro lado, y en estrecha relación con el anterior propósito, se empieza a estudiar las genealogías de las categorías socio-raciales, haciéndole un detenido seguimiento a la sobreposición de los distintos regímenes de pensamientos que las determinaban. Y más recientemente una renovada historiografía política sobre el siglo XVIII que reconsidera los significados políticos de las reformas borbónicas, está permitiendo que algunos historiadores le otorguen un peso significativo a las condiciones de vasallos y de vecinos como elementos que atravesaban las condiciones raciales y clasistas. ${ }^{8}$ Este último aspecto lo trataré en el apartado que dedico a la historiografía colombiana.

Las dos primeras direcciones llevan implícitas otra discusión sobre el uso de las distintas categorías institucionales de los mestizajes registradas en la documentación de los archivos y en la iconografía de las pinturas de las castas de Nueva España y Perú. Así, mientras que algunos historiadores prefieren desarrollar sus análisis con los conceptos aglutinantes empleados por los funcionarios de la época y le restan importancia a las pinturas de las castas, ${ }^{9}$ otros reclaman a favor de la exis-

\footnotetext{
${ }^{7}$ Verónica Undurraga, "Españoles oscuros y mulatos blancos: identidades múltiples y disfraces del color en el ocaso de la Colonia chilena. 1778-1820", en Rafael Gaune y Martín Lara (coords.), Historias de racismo y discriminación en Chile, Santiago, Uq-Bar, 2010, pp.345-373.
}

8 Federica Morelli, "La redefinición de las relaciones imperiales: en torno a la relación reformas dieciochescas/independencia en América", en Nuevo Mundo Mundos Nuevos 2008. http://goo.gl/oSZAZF; Annick Lempérière, "La recepción negativa de una grande idea: el absolutismo en Nueva España en la segunda mitad del siglo XVIII", en Mónica Quijada y Juan Bustamante (dirs.), Elites intelectuales y modelos colectivos. Mundo ibérico (siglo XVI-XIX), Madrid, Consejo Superior de Investigaciones Científicas, 2002, pp.199-218; Luis Castro Leiva, "Memorial de la modernidad: lenguaje de la razón e invención del individuo", en Antonio Annino, François-Xavier Guerra y Luis Castro Leiva (dirs.), De los Imperios a las Naciones: Iberoamérica, Zaragoza, Ibercaja, 1994, pp.129-165; Horst Pietschmann, "Protoliberalismo, reformas borbónicas y revolución: la Nueva España en el último tercio del siglo XVIII", en Josefina Z. Vázquez (dir.), Interpretaciones del siglo XVIII mexicano. El impacto de las reformas borbónicas, México D. F., Nueva Imagen, 1992, pp.27-58; Margarita Garrido, Reclamos y representaciones. Variaciones sobre la política en el Nuevo Reino de Granada 1770-1815, Bogotá, Banco de la República, 1992.

${ }^{9}$ Las distintas interpretaciones y el debate sobre los cuadros de castas puede seguirse en: Juan Carlos Estenssoro, "Los colores de la plebe. Razón y mestizaje en el Perú colonial”, en Los cuadros de mestizaje del Virrey Amat. La representación etnográfica en el Perú colonial, Lima, Museo de Arte Lima, 2000, pp.67-107; Pilar Gonzalbo, "La vida familiar y las móviles fronteras sociales en el siglo XVIII novohispano", en Montalbán n. ${ }^{\circ}$ 34, Caracas, Universidad Andrés Bello, 2001, pp.201-218; Ilona Katzew, La pintura de castas. Representaciones raciales en México del siglo XVIII, Ma- 
tencia de una diversidad de denominaciones que debieran tenerse en cuenta al momento de definir los sujetos sociales y la movilidad social. ${ }^{10}$

Relacionadas con esta diversidad de interpretaciones están los análisis sobre las polisemias y los cambios que sufrieron algunas categorías socio-raciales a lo largo del tiempo o en distintos espacios. Términos que en el siglo XVIII parecen tener una definición establecida, en los dos siglos que le precedieron eran movedizos. $\mathrm{Al}$ respecto tres ejemplos ilustran los recientes avances de la historiografía colonialista. El primero está representado en los logros de las investigaciones de Berta Ares-Queija para el caso del uso de las categorías "mulato" y "zambahigo" en Perú, ${ }^{11}$ y los de Joanne Rappaport quien se ha interesado en los detalles que permitieron ir construyendo las diferencias en el área andina del Nuevo Reino de Granada, gravitando sus reflexiones en las categorías "mestizo" y "mulato". ${ }^{2}$ Según ambas autoras el fenotipo como un elemento para identificar a las personas a partir de sus rasgos físicos aparecía subsumido en consideraciones morales y culturales (limpieza de sangre, ilegitimidad, molicie, deslealtad, poca religiosidad y urbanidad) que

drid/México D. F., Conaculta/Turner, 2004. http://goo.gl/UBp2iV; Pilar Romero de Tejada, "Los cuadros de mestizaje del Virrey Amat", en Frutas y castas Ilustradas, Madrid, Museo Nacional de Antropología/Ministerio de Educación, Cultura y Deporte, 2004, pp.11-23; Susan Deans-Smith, "Creating the colonial subject. Casta paintings, collectors, and critics in Eighteenth-Century Mexico and Spain", in Colonial Latin American Review vol.14, n. ${ }^{\circ}$, Albuquerque, University of New México, 2005, pp.169-204. http://goo.gl/1015te; Anne Ebert, "la representación de las américas coloniales en los cuadros de castas", en Scientia vol.x, n. ${ }^{\circ}$ 10, Lima, Universidad Ricardo Palma, 2008, pp.139-152. http://goo.gl/CJYqJ4; Carlos López Beltrán, "Sangre y temperamento. Pureza y mestizajes en las sociedades de castas americanas", en Frida Gorbach y Carlos López-Beltrán (eds.), Saberes locales: ensayos sobre historia de la ciencia en América Latina, Zamora, El Colegio de Michoacán, 2008, pp.289-342; María E. Velásquez, "Africanos y afrodescendientes en México: premisas que obstaculizan entender su pasado y presente”, en Cuicuilco vol.18, n. ${ }^{\circ} 51$, México D. F., Escuela Nacional de Antropología e Historia, 2011, pp.11-22.

${ }^{10}$ Ben Vinson III, "Estudiando las razas desde la periferia: las castas olvidadas del sistema colonial mexicano (lobos, moriscos, coyotes, moros y chinos)", en Juan M. de la Serna (ed.), Pautas de convivencia étnica en la América Latina colonial, México D. F., Universidad Nacional Autónoma de México, 2005, pp.247-307; "Moriscos y lobos en la Nueva España”, en M. E. Velásquez, Debates históricos contemporáneos: africanos y afrodescendientes en México y Centroamérica, pp.159178.

${ }^{11}$ Berta Ares-Queija, "Mestizos, mulatos y zambaigos (virreinato del Perú siglo XVI)", en Berta AresQueija y Alessandro Stella (coords.), Negros, mulatos, zambaigos. Derroteros africanos en los mundos ibéricos, París/Sevilla, Centre National de la Recherche Scientifique/Escuela de Estudios Hispano Americanos, 2000, pp.75-88.

12 Joanne Rappaport, “'Asi lo paresçe por su aspeto': fisiognomía y construcción de la diferencia en la Bogotá colonial”, en Tabula Rasa n. ${ }^{\circ}$ 17, Bogotá, Universidad Central, 2012, pp.13-42. 
se mezclaban con la determinación de los rasgos físicos al momento de definir a las gentes de aquellas condiciones. También demandan tener en cuenta que la instrumentalización de estos conceptos por el poder y su reflejo en los documentos oficiales ha tenido el efecto de subrayar ciertos énfasis y de esconder la existencia de una diversidad social y cultural, la que de rebote también queda opacada en la historiografía. Como ha anotado Berta Ares-Queija a propósito de las genealogías de las categorías socio-raciales en el Perú del siglo XvI,

De todas maneras, a la hora de hablar de la población de origen mixto lo más común era recurrir a expresiones englobantes del tipo "mestizos, mulatos y demás castas", que sin duda se corresponden mucho mejor con la imagen generalizadora que se desprende de cartas, informes, relaciones, cédulas [...], esto es, del discurso oficial predominante. ${ }^{13}$

En igual sentido en su estudio sobre la población indígena del corregimiento de Cuenca (Ecuador) Jacques Poloni-Simard ha alertado sobre la necesidad de analizar los conceptos socio-raciales en los contextos documentales que empleamos. Con base en la información notarial (testamentos y compraventas) del siglo XVII en las que aparecen registrados indios y personas con esa ascendencia (cholos y mestizos), este historiador ha prevenido sobre la necesidad de tener presente las diferencias entre los testamentos como documentos producidos por los sujetos interesados y las compraventas cuya elaboración estaban mediadas por la intervención de los notarios. En estas los escribanos anotaban cuando se trataba de un indios, más no sucedía así cuando era un cholo o mestizo, los que usualmente eran designados como vecinos a secas. Esta situación lo lleva a reconocer que una cosa era la categoría jurídica de la que podía escapar el mestizo y otra cosa era la esfera de su vida social. La calificación de la condición socio-racial por parte del notario dependía de la prestancia y de la posición social de los individuos, estableciéndose "[...] una dialéctica entre la definición jurídica y la posición social”. ${ }^{14}$

\footnotetext{
${ }^{13}$ B. Ares-Queija, "Mestizos, mulatos y zambaigos (virreinato del Perú siglo XVI)", p.84; "Las categorías del mestizaje: desafíos a los constreñimientos de un modelo social en el Perú colonial temprano", en Histórica vol.xviII, n. ${ }^{\circ}$ 1, Lima, Pontificia Universidad Católica de Perú, 2004, pp.204205 .

14 Jean Poloni-Simard, El mosaico indígena: movilidad, estratificación social y mestizaje en el en el corregimiento de Cuenca (Ecuador) del siglo XVI al XVIII, Quito, Abya-Yala/Instituto Francés de Estudios Andinos, 2006, pp.156-158.
} 
El tercer ejemplo lo constituye la reciente investigación de Robert Schwaller, quien siguiendo el periplo vital de la hija de una india y de un negro en Nueva España del siglo xvi que era calificada de "mulata" y no como zamba o zambahiga, muestra que en ese entonces "mulato" era una designación empleada tanto en caso de ascendientes blancos-negros como de negros-indios. Critica a una historiografía que ha mantenido una actitud displicente o huidiza frente a estas situaciones que desestabilizan la comprensión y el empleo de una categoría que solo es entendida con los parámetros del siglo xviII. También evidencia que al ganar homogeneidad en la documentación oficial la categoría "mulato" terminó por ocultar diferencias entre los sujetos coloniales. ${ }^{15}$

Y el cuarto ejemplo está representado en el ejercicio comparativo entre las colonias del Caribe continental y las insulares realizado por Stuart Schwartz, quien se pregunta sobre las especificidades de ciertas categorías propias del mestizaje como era la de "mestizo". Frente a una tradición que siempre ha medido el mestizaje tomando como referente a los blancos, Schwartz mide al mestizo de la isla de Puerto Rico tomando como referente a los negros esclavizados y las descendencias que produjeron en mezcla con otros grupos socio-raciales. Considera que el resultado fue una invisibilidad del mestizo (o al menos del término) debido a que en la Colonia temprana las relaciones entre españoles e indias fueron legalizadas a través del matrimonio y que sus descendientes (que en otras colonias fueron llamados mestizos) fueron integrados a los blancos, y en consecuencia, lo ilegítimo e impuro solo quedó asociado al mulato. ${ }^{16}$

El estudio de los desplazamientos (y sus limitaciones) de distintos actores sociales por una escala ascendente de categorías socio-raciales gracias a los procesos de blanqueamiento y el acceso a ciertos niveles de fortuna, tiene en las investigaciones de Ann Twinam los mejores aportes. En un texto que está por ver la luz pública dedicado al estudio detallado del blanqueamiento por vía de las gracias al sacar, esta historiadora se pregunta sobre lo que esto representó para las gentes de color de las colonias hispanoamericanas. Se trata de una pregunta crucial porque

\footnotetext{
15 Robert Schwaller, "'Mulata, hija de negro y india': Afro-Indigenous Mulatos in Early Colonial Mexico", in Journal of Social History vol.44, n. ${ }^{\circ}$ 2, Oxford, Oxford University Press, 2011, pp.889914. http://goo.gl/uLQkHR.

${ }^{16}$ Stuart Schwartz, "Spaniards, 'pardos', and the missing mestizos: identities and racial categories in the early hispanic Caribbean", in New West Indian Guide vol.71, n. ${ }^{\circ} 1-2$, Amsterdam, Royal Netherlands Institute of Southeast Asian and Caribbean Studies, 1997, pp.5-19. http://goo.gl/4Gu6Sp.
} 
una historiografía reciente especula con la gracia al sacar como una de las pruebas de la pérdida de importancia del factor racial. Para afrontar estos problemas Twinam hace un seguimiento al lenguaje social de la época que estudia (raza, mulato, pardo), y hace de los estudios de casos el epicentro de sus reflexiones para mostrar las posibilidades y limitaciones de la dinámica social fundada en los procesos de blanqueamiento. ${ }^{17}$

Por otra parte se comienza a estudiar las genealogías de las categorías socioraciales develándose sus enmarañados orígenes y sus relaciones con el poder y la escritura. Una de las conclusiones más significativas es la de que es un anacronismo llevar el pensamiento racial formulado en el siglo XIX a las centurias que le precedieron, al igual que no necesariamente las categorías socio-raciales del XVIII son válidas para los dos siglos que le antecedieron. De igual forma se acepta que las categorías sociales coloniales eran el resultado de la sobreposición de estratos de distintas epistemologías que hundían sus raíces hasta el medioevo español. Max Hering Torres, María E. Chaves, Eduardo Restrepo, Marisol de la Cadena y otros historiadores y antropólogos han realizado un trabajo de arqueología del discurso al rastrear los diversos orígenes religiosos y políticos de los fundamentos que dieron origen al término "mestizo" en la España medieval, y han mostrado la acumulación de diversos sustratos culturales de esa categoría, las jerarquías que se establecían entre estos y cómo terminó siendo un concepto naturalizado por los discursos raciales de los siglos XVIII y XIX.18

\footnotetext{
17 Ann Twinam, “American Defects:" Pardos, mulatos and the quest for whiteness in the Spanish Indies, Stanford, Stanford University Press, en prensa. Agradezco la gentileza de la autora por el envío de una copia del capítulo 2. "Pedro de Ayarza. The purchase of whiteness", in Kenneth Andrien (ed.), The human tradition in Colonial Latin America, Lanham, Rowman \& Littlefield, 2002, pp.194-210; "The etiology of racial passing: Constructions of informal and official "Whiteness" in Colonial Spanish America", in John Smolenski and Thomas Humphrey (eds.), New World Orders, Violence, Sanction, and Authority in the Early Modern Americas, Philadelphia, University of Pennsylvania Press, 2005, pp.249-272; Vidas públicas, secretos privados. Género, honor, sexualidad e ilegitimidad en la Hispanoamérica colonial, México, Fondo de Cultura Económica, 2009.

${ }^{18}$ Max Hering Torres, "Color, pureza, raza: la calidad de los sujetos coloniales", en Heraclio Bonilla (ed.), La cuestión colonial, Bogotá, Ed. Norma, 2011, pp.451-469; "La limpieza de sangre en España: un modelo de interpretación”, en Nikolaus Böttcher, Bernd Hausberger y Max Hering Torres (eds.), El peso de la sangre. Limpios, mestizos y nobles en el Mundo Hispánico, México D. F., El Colegio de México, 2011, pp.23-54; María E. Chaves, "La creación del 'otro' colonial. Apuntes para un estudio de la diferencia en el proceso de la conquista americana y de la esclavización de los africanos", en María E. Chaves (ed.), Genealogías de la diferencia. Tecnologías de la salvación y representación de los africanos esclavizados en Iberoamérica colonial, Bogotá, Universidad Javeriana, 2009,
} 


\section{Los censos de población como objeto de estudio}

Estas reconsideraciones han llevado a cuestionar las relaciones entre las interpretaciones historiográficas y las informaciones documentales en que se basan, obligando a los historiadores a realizar trabajos de deconstrucción de las fuentes. También está exigiendo triangular los censos con nuevas informaciones de archivos que no se habían tenido en cuenta tales como los expedientes judiciales, las documentaciones notarial, parroquiales y otras originadas en los actos de las autoridades locales. Esas exploraciones documentales se acompañan con una actitud crítica frente a las informaciones que contienen, convirtiéndolas en objeto de análisis con el fin de avanzar en el estudio de los discursos de esa época, como también para conocer las huellas que estos han dejado en los documentos que nos han legado las personas y las instituciones.

En el centro de estas reflexiones se han colocado los censos de población realizados durante el periodo colonial, debido a que constituyen la fuente de información más utilizada por los historiadores cuando se refieren a la configuración socio-racial de ese entonces. En los padrones del siglo XVIII se han identificado tres bloques de problemas. Un primer conjunto que podemos llamar de base se refiere a las limitaciones que poseen como fuentes de información debido a la rigidez de la imagen que brindan de la sociedad. Relacionado con el anterior un segundo bloque está constituido por las necesidades de conocer cómo se construyeron los censos

pp.178-243; Eduardo Restrepo, "El negro en un pensamiento colonial de principios del siglo XVII: diferencia, jerarquía y sujeción sin racialización", en M. E. Chaves, Genealogías de la diferencia. Tecnologías de la salvación y representación de los africanos esclavizados en Iberoamérica colonial pp.119-176; Marisol de la Cadena, “¿son los mestizos híbridos? las políticas conceptuales de las identidades andinas”, en Marisol de la Cadena (ed.), Formaciones de indianidad. Articulaciones raciales, mestizaje y nación en América Latina, Popayán, Ed. Envión, 2007, pp.83-116; Verena Stolcke, "Los mestizos no nacen sino que se hacen", en Verena Stolcke y Alexandre Coello (comp.), Identidades ambivalentes en América Latina (siglos XVI-XXI), Barcelona, Eds. Bellaterra, 2008, pp.14-51; C. López Beltrán, "Sangre y temperamento. Pureza y mestizajes en las sociedades de castas americanas", pp.289-342; Kathryn Burn, "Desestabilizando la raza", en M. de la Cadena, Formaciones de indianidad. Articulaciones raciales, mestizaje y nación en América Latina, pp.35-54. Algo parecido se viene haciendo con la categoría de "criollo". Alexandre Coello y Paulina Numhauser, "Introducción: Criollismo y mestizaje en el mundo andino (siglos XVI-XIX)", en Illis i Imperis n. ${ }^{\circ} 14$, Barcelona, Universitat Pompeu Fabra, 2012, pp.13-48. David Cahill ha ido mucho más atrás al señalar como las consideraciones morales-culturales también tuvieron una raíz en las conflictivas relaciones entre los distintos grupos que formaron el imperio Inca. "Colores cifrados: categorías raciales y étnicas en el virreinato peruano, 1532-1824”, en Nueva Síntesis n. ${ }^{\circ} 7-8$, Lima, Universidad de San Marcos, 2001, pp.29-58. 
por parte de las instituciones coloniales (iglesia y autoridades ordinarias y militares), lo que remite a las formas como los funcionarios eclesiásticos, burócratas y oficialidad militar concebían a la sociedad y a sus distintos grupos, y a los discursos y el mundo de representaciones sobre el orden y los sectores sociales. Y el tercer acumulado de problemas hace referencia a las relaciones entre las clasificaciones socio-raciales consignadas por los empadronadores y las formas como se autoreconocía la población censada y la imagen que tenía la comunidad de cada uno de sus miembros y sus familias.

Acerca del tema de la imagen sincrónica de la sociedad creemos que a estas alturas de los avances de la historiografía no es mucho lo que hay que agregar. Al respecto solo anotemos de paso que el problema de los censos radica en el hecho de contener identidades recortadas sobre los individuos y sus familias, los que en la vida real ponían en escenas diversas imágenes sociales avaladas o desvalorizadas por los distintos sectores sociales. No existía una relación invariable entre las denominaciones sobre las calidades que se registraron en los padrones y las prácticas sociales que relacionaban a los individuos y que crearon los contextos políticos y socio-culturales en que estaban inscritas las clasificaciones socio-raciales. Además, eran móviles las fronteras entre algunas de las categorías registradas en los padrones.

Los dos conjuntos restantes de problemas se refieren a la necesidad de conocer las técnicas de recolección de la información por parte de los empadronadores, los significados de las categorías clasificatorias empleadas y las formas identitarias que asumían los empadronados y las que les asignaban los funcionarios que levantaban los censos. ${ }^{19}$ Esas preocupaciones están vinculadas con tres preguntas claves

${ }^{19}$ Un buen resumen sobre algunos problemas de los censos del siglo XviII de Brasil en Carlos de Almeida Prado Bacellar, "Las listas nominativas de los habitantes de la capitanía de São Paulo, Brasil, bajo una mirada crítica”, en Dora Celton, Mónica Ghirardi y Adrián Carbonetti (coords.), Poblaciones históricas. Fuentes, métodos y líneas de investigación, Rio de Janeiro, Asociación Latinoamericana de la Población, 2009, pp.155-170. http://goo.gl/cenMLK. Por otras informaciones también sabemos que eran común las manipulaciones que los individuos podían hacer de sus condiciones socio-raciales de acuerdo con las expectativas que tuvieran. B. Vinson III, "Estudiando las razas desde la periferia", pp.271-272; J. Garavaglia y J. Grosso, "Criollos, mestizos e indios: etnias y clases sociales en el México colonial a finales del siglo XVIII”, pp.39-80. Para el caso de los censos del Nuevo Reino de Granada ver Sergio Paolo Solano, "Representaciones socio-raciales en el Nuevo Reino de Granada del siglo XVIII: censo de 1777, listados de milicianos y juicios por ofensas al status y al honor", en José Polo y Rafael Acevedo (eds.), Poder y formas de sociabilidad en Colombia, 17501850, Medellín, Universidad de Cartagena/La Carreta Eds., 2014, (en prensa); "Poder, escritura y representaciones sociales. Configuración socio-racial del Nuevo Reino de Granada, siglo XVIII”, en 
que empiezan a orientar las investigaciones históricas. a) Las formas como los funcionarios ordinarios, eclesiásticos y militares concebían a la sociedad y las relaciones de los distintos grupos con las instituciones. ${ }^{20}$ b) Las relaciones entre las necesidades de las instituciones, autoridades coloniales, y la realización y los usos que hacían de los censos. Y c) las posibles correspondencias y asimetrías entre las imágenes institucionales y las formas como las comunidades leían y asignaban las posiciones de las personas en la jerarquía social, y también a las lecturas que las personas hacían de sí mismas.

Publicaciones recientes empiezan a asumir el estudio de esos problemas. Las investigaciones evidencian la existencia de unas conflictivas relaciones entre las definiciones jurídicas de los distintos grupos socio-raciales, las endocategorizaciones de las comunidades, las exo-clasificaciones realizadas por funcionarios, curas y militares, y las auto-calificaciones de las personas. Todo va a depender de las características de las sociedades empadronadas, como también de un conjunto de circunstancias locales y de las relaciones de los individuos y familias con la riqueza y con el poder. Respecto a las formas como se levantaba la información depositada en los censos, en especial la relativa a la condición socio-racial de las personas, algunos historiadores han insistido en develar las prácticas que desde arriba permitían a los funcionarios imputar identidades a las poblaciones y sus habitantes.

Por ejemplo, a propósito de las clasificaciones socio-raciales registradas en el censo de 1791 de la pequeña villa de Tepeaca (Nueva España), Juan C. Garavaglia y Juan C. Grosso consideraron que muchas de las categorizaciones de las personas en unos compartimientos sociales no dependían de las formas como los habitantes se auto-percibían sino de la idea que se hacía el empadronador con base en lo que consideraba una especie de "objetividad" de clasificación. ${ }^{21}$ En parecido sentido Brígida von Mentz ha hecho un llamado para que los historiadores tengan en cuenta las relaciones entre registradores y registrados al momento de emplear los cen-

\footnotetext{
Memorias vol.11, n. ${ }^{\circ}$ 23, Barranquilla, Universidad del Norte, 2013, (en prensa).

${ }^{20}$ Steinar Saether, "Counting indians: census categories in late colonial and early republican Spanish America”, in Per Axelsson and Peter Sköld (eds.), Indigenous peoples and demography. The complex relation between identity and statistics, Oxford, Berghahn Books, 2011, p.58.

${ }^{21}$ J. Garavaglia y J. Grosso, "Identidad, identidades: una visión desde la América hispana, siglos XVIII-XIX", p.26.
} 
sos en sus análisis. Por un lado analiza los vínculos entre la tradición indígena nahua de registrar a la población y las innovaciones que introdujeron los españoles durante la conquista. Por otra parte estudia la capacidad lecto-escritora de los personajes locales que levantaron algunas matrículas en 1540, y sus funciones de intermediarios culturales entre la población empadronada y las instituciones coloniales en el área de Cuernavaca. También muestra las modificaciones que se operaron en 1671 cuando los registradores fueron curas franciscanos que se hallaban en conflictos con los habitantes de la comarca, hecho que incidió en que no respetaran las autodefiniciones de los empadronados, y que todos fueran calificados como "indios". 22

Algo parecido ha anotado Patrick J. Carroll a propósito de la discusión que involucra las relaciones entre raza-clase-calidad, el papel de los padrones de población en las políticas oficiales y en las distintas identidades que las personas y familias ponían en escena. Considera que en algunos casos los empadronadores (sacerdotes y funcionarios) pudieron aplicar la técnica de "raza por reputación", asignando condiciones socio-raciales en concordancia con las características mayoritarias de la población de determinado lugar. O que procedieron motivados por el interés en presentar una imagen reforzada del sistema de castas, estableciendo unas identidades colectivas a una totalidad que en términos reales podían estar fraccionadas. También piensa que muchas veces los sacerdotes registraban las identidades que declaraban los individuos, los que podían manipular su ubicación en el orden socio-racial, y que en otras ocasiones los curas podían aprovechar un padrón para asignar una condición baja a las personas y sectores con los que tenían conflictos. De igual forma, por sus apegos a la defensa del sistema de castas los sacerdotes podían ignorar o distorsionar los casos en que los hechos estaban en contravía con ese sistema. ${ }^{23}$

En otros casos sucedió que los empadronadores recogieron lo que las personas y las comunidades consideraban que era la condición socio-racial de cada

\footnotetext{
${ }^{22}$ Brígida von Mentz, "La elaboración de matrículas poblacionales y el contexto social. Análisis de dos tradiciones estatales y de la relación entre registradores y registrados en la región de Cuernavaca, 1540-1671", en América Molina y David Navarrete (coords.), Problemas demográficos vistos desde la historia, Zamora, El Colegio de Michoacán/Centro de Investigaciones y Estudios Superiores en Antropología Social/Conacyt, 2006, pp.29-66.

${ }^{23} \mathrm{P}$. Carroll, "El debate académico sobre los significados sociales entre clase y raza en el México del siglo XVIII”, pp.111-142.
} 
quien. En el levantamiento del padrón de la población de 1777 de Santiago de Querétaro (Nueva España) "[...] el cura indicaba que las calidades de los miembros asentados se obtenían a partir 'de lo que cada uno declaró', y no a partir de la revisión, por ejemplo, de los libros de bautismos o de matrimonios o de las matrículas de tributos del curato”. ${ }^{24}$ En un par de artículos recientes he señalado que en el censo de 1777 del Nuevo Reino de Granada participaron muchos empadronadores que eran vecinos de las localidades y con conocimientos de sus habitantes, lo que hace pensar que en no pocos casos la determinación de las condiciones socioraciales de las personas fue producto de negociaciones entre la lectura del empadronador, la forma como se auto-percibía el empadronado y lo que había consagrado la tradición social local. En la documentación colonial estas formas de conocer aparecen referenciadas como "de vista, trato y comunicación". Francisco Moreno y Escandón, fiscal de este virreinato lo expresó en una circular que acompañó la orden real de noviembre de 1776 que obligaba a realizar padrones en todas las colonias, demandando que se efectuara la "[...] descripción de los habitadores de su distrito, sin mover disputa para indagar las clases, y castas de cada uno, sino colocándolos en aquellas en cuya posesión estuviesen". ${ }^{25}$

En ciertos casos ese conocimiento era esencial para la elaboración de los listados de las milicias disciplinadas, pues en 1779 don Diego Antonio Nieto, maestre de campo y encargado de organizar las milicias en la provincia de Popayán informaba al virrey Manuel Antonio Flórez cuál era su actitud al tener que determinar la condición socio-racial de los milicianos:

[...] deseoso yo de no ser instrumento para promover fastidiosas disputas sobre un asunto en el que concurren muchos intereses por estos parajes, y por evitar otros mayores inconvenientes para formar las milicias no he querido hacer por mí los primeros padrones, con la correspondiente distinción de castas. Los he

\footnotetext{
${ }^{24}$ Ernest Sánchez, "El nuevo orden parroquial de Ciudad de México: población, etnia y territorio (1768-1777)", en Estudios de Historia Novohispana n. ${ }^{\circ} 30$, México D. F., Universidad Nacional Autónoma de México, 2004, p.64.

25 Archivo General de la Nación (Colombia), Sección Colonia, fondo Censos Redimibles-Censos Varios Departamentos (AGN, SC, CR-CVD), leg.8, f.225r. Cursivas mías. S. P. Solano, "Representaciones socio-raciales en el Nuevo Reino de Granada del siglo XVIII: censo de 1777, listados de milicianos y juicios por ofensas al status y al honor", (en prensa); "Poder, escritura y representaciones sociales. Configuración socio-racial del Nuevo Reino de Granada, siglo XVIII", (en prensa).
} 
recibido de las justicias en quienes he debido considerar un cabal conocimiento de cada individuo. ${ }^{26}$

En otras ocasiones los empadronadores mostraron desconfianza con las autocalificaciones de los habitantes. Por ejemplo, en 1790 el cura del pueblo de Venero, jurisdicción de Tamalameque (provincia de Santa Marta, en el Nuevo Reino de Granada), realizó un padrón de los indios Chimilas y de los vecinos libres ahí avecindados. Al final advirtió: “[...] asimismo van de bulto las clases, pues algunos de ellos mismos la ignoran, y otros quieren ser más de lo que Dios lo ha hecho”.27 En el censo de 1777 de la ciudad de Salazar de las Palmas (provincia de Pamplona) se anotó:

Nota. Que esta Faviana Pérez, siendo hija de matrimonio trató de negar a su padre por ser mulato, apropiándose por padre a un hombre blanco, porque su madre era mestiza, para que sus hijos corriesen por tales de que dio información, y se dio otra de contrario con 15 testigos, y otros certificados, con lo que quedan en el ser de mulatos, en que Dios los creó. ${ }^{28}$

De una familia se dice: "según voz común [pertenece] a la $3^{\mathrm{a}}$ clase". ${ }^{29} \mathrm{O}$ en el caso de un vecino de la parroquia de San Miguel (perteneciente a la jurisdicción provincial antes señalada), se resaltó una nota del empadronador que rezaba que un hombre era "[...] hijo de mujer noble, y por su padre corre por mulato y esta calidad no se explica más por no ser su padre de este lugar [...]". ${ }^{30}$ Los tres ejemplos evidencian que en la determinación de la calidad de las personas el conocimiento de la ascendencia familiar era pieza clave, siguiendo en esto un patrón de indagación y determinación muy generalizado, como sucedía con los pleitos judiciales por considerar difamada la honra o menoscabado el estatus social.

\footnotetext{
${ }^{26}$ AGN, SC, fondo Milicias y Marina, leg.52, f.443r.

${ }^{27}$ AGN, SC, fondo Curas y Obispos, leg.27, f.811r.

${ }^{28}$ AGN, SC, CR-CVD, leg.6, f.463v.

${ }^{29}$ AGN, SC, CR-CVD, leg.6, f.466v.

${ }^{30}$ AGN, SC, CR-CVD, leg.8, f.538v.
} 
Pero las instituciones y los funcionarios también intervenían y podían clasificar a una persona en una situación distinta a la que esta reivindicaba, lo que podía pasar o no desapercibido dependiendo de la calidad y del status de las personas, como también de las implicaciones jurídicas que tuvieran esas catalogaciones. Y asimismo sucedía que mediaban las estrategias de las personas para eludir el pago de los impuestos mediante el cambio de identidad socio-racial, actitud que a su vez estaba asociada a la idea de que los padrones se realizaban para aumentar las cargas fiscales sobre determinados grupos sociales. Quiere esto decir que un factor clave para entender las identidades socio-raciales fue la actitud de las gentes frente a las políticas fiscales de la Corona española y de las autoridades coloniales. Lo que evidencian muchos expedientes de los fondos "Tributos" y "Caciques e indios" como también algunos del fondo "Miscelánea" del Archivo General de la Nación de Colombia son los juegos de las identidades socio-raciales desarrollados por sectores de la población acorde con sus intereses frente al pago de impuestos. Berta AresQueija ha sugerido que en el estudio de estos temas se debe tener presente que durante el siglo XVI fue la política fiscal del tributo la que tuvo un efecto diferenciador sobre el discurso oficial y eclesiástico relativo a los distintos grupos. Hasta el momento ambas autoridades empleaban terminologías genéricas para referirse a las distintas mezclas socio-raciales que se estaban produciendo en el Perú hasta la primera mitad de ese siglo. Pero el tributo que pagaban los indios y los intentos por generalizarlos a los demás sectores de la población produjo actitudes diferenciadoras entre los pobladores y en los discursos institucionales. ${ }^{31}$

Otro tanto se ha realizado respecto al análisis de las relaciones entre las necesidades de las instituciones político-administrativas, los contextos políticosociales en los momentos en que se levantaron los padrones y las características de la información recolectada, en especial, los motivos que tenían las autoridades para celebrar los censos y la configuración socio-racial que contienen. Así tenemos matrículas de indios; censos eclesiásticos; padrones por necesidades militares y fiscales; otros realizados por el imperativo de conocer a la población para los propósitos de la administración del Imperio y de los virreinatos y capitanías. Y otros llevados a cabo por iniciativas locales desarrollados por autoridades o por los notables de una

\footnotetext{
${ }^{31}$ Berta Ares-Queija, "A los hijos de español y de india, o de indio y española, nos llaman mestizos... Construcciones identitarias en la América colonial española”. Conferencia en el Instituto de Estudos Avancados Transdisciplinares-Universidade Federal de Minas Gerais (sin fecha), p.8. http://goo.gl/ohx4Jo; "Las categorías del mestizaje: desafíos a los constreñimientos de un modelo social en el Perú colonial temprano", pp.200-203.
} 
población con el propósito de lograr una mejor categoría en la jerarquía del poblamiento.

Por ejemplo, en 1708 se celebró en Cartagena de Indias un empadronamiento de la población masculina con fines militares debido a que pocos años antes (1697) la ciudad había sido tomada por el barón de Pointis, arrojando la cifra de 622 vecinos en capacidad de tomar las armas para la defensa. ${ }^{32}$ El censo de Puerto Rico de 1765 realizado por orden de Alejandro O’Reilly, se hizo por temor a que esta isla fuera tomada por los británicos como lo había sucedido tres años antes con La Habana. ${ }^{33}$ También razones de defensa explican, según María Andreazza, que en Curitiba, sur de Brasil, se haya realizado un censo en 1765, el que solo contabilizó a los hombres debido al interés de las autoridades de tener un registro de quienes pudieran tomar las armas para participar en la guerra luso-castellana (1762-1777) y defenderse de las entradas de gentes provenientes de las fronteras con Buenos Aires y Asunción. Por eso las clasificaciones fueron: "ausentes", "los que han nacido en el reino", "criminales", "incapaces", "indios de la tierra”, pardos", "negros" y "esclavos" ${ }^{34}$ El de Montevideo de 1772-1773, conocido como el Padrón Aldecoa, se debió a necesidades militares por lo que registró a los pobladores que debían pagar impuestos para el sostenimiento de las milicias, señalando la existencia de indios, negros, negros libres, mestizos, mulatos, pardos, esclavos y muchos otros hombres que por ser españoles y portugueses suponemos que debían ser blancos. ${ }^{35} \mathrm{Ada} F \mathrm{Fe}-$ rrer argumenta que los censos realizados en Cuba contemporáneos y posteriores a la Revolución de Haití (1791-1804) fueron motivados por el temor que suscitaba

\footnotetext{
32 61,7\% blancos; 24,2\% pardos libres; 13,0\% negros libres. Carmen Gómez, "La población de Cartagena de Indias a principios del siglo XVIII", en Temas Americanistas n. ${ }^{\circ}$, Sevilla, Universidad de Sevilla, 1983, pp.43-52.

${ }^{33}$ Katherine J. Curtis and Francisco Scarano, “Puerto Rico's population padrones, 1779-1802", in Latin American Research Review vol.46, n. ${ }^{\circ}$ 2, Pittsburgh, Latin American Studies Association, 2011, pp.200-213. http://goo.gl/qE7qFx.

${ }^{34}$ María Andreazza, "El papel de los censos en la producción de las categorías sociales y espaciales de las colonias americanas", en D. Celton, M. Ghirardi y A. Carbonetti, Poblaciones históricas. Fuentes, métodos y líneas de investigación, pp.117-135. http://goo.gl/cenMLK.

35 Archivo General de la Nación (Argentina), División Colonia; Sección Gobierno; Montevideo, leg.76; 1730-1804; Sala IX, 3-1-8. La transcripción de este padrón puede leerse en la web Pueblos y Números. Rio de La Plata 1760-186o. http://goo.gl/PwKTiK. Un estudio y transcripción de este padrón puede leerse en Juan A. Apolant, "Padrones olvidados de Montevideo del siglo XVIII [II]. Padrón Aldecoa 1772-1773", en Boletín Histórico n. ${ }^{\circ}$ 106-107, Montevideo, Ejército de Uruguay, 1965, pp.47-149. http://goo.gl/gwDzOa.
} 
que aquella isla también fuese escenario de un parecido levantamiento social de gentes de color. El miedo originó el interés en conocer, controlar y vigilar a la población, lo que se expresó en el levantamiento de los padrones (los generales de 1791-1792 y 1817 realizados por orden de la Corona, y muchos provinciales realizados por iniciativas de las autoridades locales). ${ }^{36}$

El censo de Nueva España de 1777, llamado censo de Bucareli por el apellido del virrey que lo ordenó, se hizo cumpliendo el decreto real de noviembre del año anterior que mandaba a que se contabilizara a la población con la debida distinción de clases, estados y castas de todas las personas de ambos sexos sin excluir a los párvulos. Su realización tuvo un doble encargo con dos resultados: un censo lo realizaron las autoridades ordinarias y fue desarrollado teniendo como unidad territorial las jurisdicciones de las alcaldías. El otro fue desarrollado por los sacerdotes con base en la unidad territorial del curato. Un estudio de este padrón señala que tanto las necesidades fiscales del reformismo borbónicos y las militares después de las derrotas frente a los ingleses y las pérdidas en 1762 de Manila y La Habana, como el desarrollo del pensamiento ilustrado que empezaba a matematizar al mundo social, están en la base de su realización. ${ }^{37}$ Estudios de ese censo para algunas ciudades señalan que pese a que se diseñó un formulario al que debían atenerse los curas-empadronadores, ${ }^{38}$ existió una diversidad de formas en su desarrollo por localidades. ${ }^{39}$ En casi todos los padrones por localidades se especificaron la diversidad socio-racial de ese entonces, como lo hicieron los padrones de la ciudad de México (españoles, indios, mestizos, mulatos, castizos y otros), ${ }^{40}$ y de Durango (casti-

\footnotetext{
${ }^{36}$ Ada Ferrer, "Cuba en la sombra de Haití: Noticias, sociedad y esclavitud", en María González, Consuelo Naranjo, Ada Ferrer y José Opatrný, El rumor de Haití en Cuba: temor, raza y rebeldía, 1789-1844, Sevilla, Consejo Superior de Investigaciones Científicas, 2004, pp.203-209.

${ }^{37}$ Ernest Sánchez, Padrón del arzobispado de México 1777, México D. F., Archivo General de la Nación, 2003, pp.15-17.

38 Carmen Castañeda y Laura Gómez, "La población de Guadalajara de acuerdo con el padrón militar de 1791 y el censo de la intendencia de 1793", en Historias n. ${ }^{\circ} 76$, México D. F., Instituto Nacional de Antropología e Historia, 2000, p.45. http://goo.gl/d6KjRp.

${ }^{39}$ Sherburne F. Cook y Woodrow Borah, Ensayos sobre la historia de la población. México y el Caribe I, vol.1, México D. F., Siglo XXI, 1998, pp.142-143, 145-147; E. Sánchez, Padrón del arzobispado de México 1777, p.38.

${ }^{40}$ Ernest Sánchez, "La población de la Ciudad de México en 1777", en Secuencia n. ${ }^{\circ} 60$, México D. F., Instituto Mora, 2004, p.39. Otra categorías socio-raciales de escasa presencia según ese padrón era: mestindios, coyotes, lobos, moriscos, negros y albinos. Carlos Contreras y Claudia Pardo, "La cuenta
} 
zos, coyotes, españoles, jíbaros, indios, lobos, mulatos, moriscos, mestizos, negros). ${ }^{41}$ Con base en los censos de las localidades se realizaron resúmenes, los que se remitían a la Secretaría del Arzobispado de Nueva España, para llevar a cabo el cuadro general para todo el arzobispado, el que se terminó en 1779.42

El padrón de 1778 de Buenos Aires y su provincia no registró unidades familiares, sino a las personas por grupos socio-raciales ("blancos, indios, mulatos y negros"), resaltando el grado militar de los varones. ${ }^{43}$

De toda Hispanoamérica el censo más estudiado es el de Nueva España de 1790, conocido como del conde de Revillagigedo, por el nombre del virrey que lo ordenó, padrón que desde sus orígenes suscitó un debate que aún no culmina sobre su validez. ${ }^{44}$ Los estudios por ciudades y provincias han puesto en limpio que este padrón siguió la metodología que en 1787 había sido el fundamento del censo español del conde de Floridablanca. Por eso su organización demandó dos modelos o formatos: 1) El modelo para registrar la población de las distintas localidades haciendo alusión a edades, calidades, clases estado civil y ocupaciones; 2) el modelo para que las autoridades de cada intendencia y/o provincia presentara el resumen. 45

de feligreses en Puebla de los Ángeles en 1777. Población y estructura racial”, en Carlos Contreras y Claudia Pardo (coords.), El Obispado de Puebla. Españoles, indios, mestizos y castas en tiempos del virrey Bucareli, 1777, Puebla, Benemérita Universidad de Puebla/Instituto de Ciencias Sociales y Humanidades "Alfonso Vélez Pliego", 2007, pp.29-71. En parecida tónica estuvo el censo de Chile de 1777-1778. Retratos de nuestra identidad: Los censos de población en Chile y su evolución histórica hacia el Bicentenario, Santiago de Chile, Instituto Nacional de Estadística, 2009, pp.49-54. http://goo.gl/EtWjz3.

${ }^{41}$ María Juárez, Estructura poblacional de Durango en 1778, México D. F., trabajo de grado licenciada en Historia Universidad Autónoma Metropolitana-Iztapalapa, 1998, pp.44-69, 91-92. http://goo.gl/BqOVXo.

42 E. Sánchez, Padrón del arzobispado de México 1777, pp.36-37. El resumen general puede consultarse en: AGI, Mapas y Planos, Varios, exp.38.

43 Sandra Olivero, Sociedad y economía en San Isidro colonial. Buenos Aires, siglo XVIII, Sevilla, Universidad de Sevilla, 2006, pp.49-50.

${ }^{44}$ Sonia Pérez Toledo, Población y estructura social de la Ciudad de México, 179o-1842, México D. F., Universidad Autónoma Metropolitana/Conacyt, 2004, p.70.

45 Áurea Commons, “La población de Nueva España en 1790”, en Tempus n. ${ }^{\circ} 3$, México, D. F., Universidad Nacional Autónoma de México, 1995, pp.10-11. http://goo.gl/I837CZ. 
Tuvo diversos propósitos: conocer a la población para establecer políticas gubernamentales y fiscales, por lo que se registraron los oficios y las condiciones socio-raciales de los hombres. También tubo fines tributarios con relación a la población indígena. Y no faltaron los propósitos militares insistiendo en el registro de la población masculina mayor de 12 años. ${ }^{46}$ Por este motivo, por ejemplo, en Xalapa (en el área de la sierra que da hacía las costas de Veracruz) solo se contabilizó a la población libre y se excluyeron a los indios y a los esclavos, ${ }^{47}$ mientras que en Ciudad de México se contabilizaron las distintas castas al igual que en las Huastecas, Guadalajara y Querétaro. ${ }^{48}$

En el estudio de las genealogías de las categorías socio-raciales que organizaban a la población en los censos, se analiza cómo se cruzaron las formas eclesiásticas y civiles en la realización de los padrones de población. Las investigaciones sobre las relaciones entre los censos civiles con los padrones de feligresías y libros de bautismos, matrimonios y defunciones que llevaban las iglesias, están permitiendo determinar cómo las categorías que se empleaban en estos últimos transitaron a un uso generalizado. ${ }^{49}$ Por ejemplo, para el caso del Chile colonial Alejandra

${ }^{46}$ Hugo Castro, Primer censo de la población de la Nueva España, 179o. Censo de Revillagigedo "un censo condenado", México D. F., Dirección General de Estadísticas, 1777. http://goo.gl/VjWWd5; Leticia Mayer, "Los censos novohispanos a finales del siglo XVIII". Ponencia leída en el Congreso de la Latin American Studies Association, Rio de Janeiro, junio de 2009. http://goo.gl/oZ2ojt.

${ }^{47}$ Patrick J. Carroll, "Estudio socio-demográfico de las personas de sangre negra en Jalapa, 1791", en Historia Mexicana vol.xxiII, n. ${ }^{\circ}$, México D. F., El Colegio de México, 1973, p.114. Sobre el propósito militar de este censo ver: Matilde Souto Mantecón, "Composición familiar y estructura ocupacional de la población de origen español en Jalapa de la Feria (1791)", en Estudios de Historia de Nueva España n. ${ }^{\circ}$ 27, México D. F., Universidad Nacional Autónoma de México, 2002, pp.93-95.

48 Manuel Miño, "Para la historia social. Tablas de edad, estado marital y grupos raciales de la población de la Ciudad de México, 1790 (13 cuarteles)", en Historia Mexicana vol.LVII, n. ${ }^{\circ}$, México D. F., El Colegio de México, 2008, pp.911-944; Antonio Escobar, "La estructura socioeconómica de las Huastecas en el siglo XVIII. El censo militar de 1791", en La Palabra y el Hombre n. ${ }^{9} 96$, Veracruz, Universidad Veracruzana, 1995, pp.5-36; Celia Wu, "La población de la ciudad de Querétaro en 1791", en Historias n. ${ }^{\circ}$ 20, México D. F., Instituto Nacional de Antropología e Historia, 1988, pp.6788. http://goo.gl/dGzqCI; C. Castañeda y L. Gómez, "La población de Guadalajara de acuerdo con el padrón militar de 1791 y el censo de la intendencia de 1793"; H. Castro, Primer censo de la población de la Nueva España, 1790.

${ }^{49}$ Ver los orígenes eclesiásticos y las transformaciones operadas en algunas categorías socio-raciales en Norma Castillo, "Informaciones y probanzas de limpieza de sangre. Teoría y realidad frente a la movilidad social de la población novohispana producida por el mestizaje”, en N. Böttcher, B. Hausberger y M. Hering Torres, El peso de la sangre. Limpios, mestizos y nobles en el mundo hispánico, 
Araya distingue la existencia de una tradición eclesiástica (confesional-parroquial con sus libros de bautismos, matrimonios y defunciones, matrículas de feligresías), y otra civil (repartimientos de indios, visitas a la tierra para tasar tributos, y censos con fines impositivos y militares). Ambas ordenaban a la población por condición socio-racial, lo que se había originado en una disposición real de 1573 para que en las iglesias los ritos religiosos y sacramentos se llevaran en libros separados de acuerdo a las condiciones de las personas que los recibían. A estas tradiciones en la segunda mitad del siglo XVIII se le sumaron lo que Araya llama "proto-censal", caracterizada por técnicas más precisas de contabilización de la población y una tradición militar. 50

Algunas investigaciones han alertado sobre lo saludable que es tener una perspectiva comparativa de diversos censos de una misma población, y han resaltado la necesidad de analizar con cuidado el tratamiento que los empadronadores daban a las personas y familias de acuerdo al estado civil, ocupación y el género. Para avanzar en esta dirección ha sido necesario pasar del uso de los resúmenes de los censos al empleo de los padrones de las poblaciones.

Comparando varios censos de Santiago de Cuba, María Meriño y Aisnara Perera han mostrado como las clasificaciones socio-raciales podían variar acorde con la ocupación, y con el hecho de si el jefe de familia estaba vivo o si ya había fallecido. Así, mujeres clasificadas como blancas mientras sus esposos de igual condición estuvieron vivos, una vez enviudaban se les rebajó el status y aparecieron registra-

pp.219-250. De esta autora también ver: Cholula. Sociedad mestiza en ciudad india. Un estudio sobre las causas económicas, sociales y demográficas del mestizaje en una provincia novohispana, México D. F., Universidad Autónoma Metropolitana-Iztapalapa/Plaza y Valdés, 2001, pp.76-200. Sobre los orígenes de las categorías mestizo, mulato y zambo en la audiencia de Lima del siglo XVI ver: K. Burn, "Desestabilizando la raza", pp.35-54; B. Ares-Queija, "Mestizos, mulatos y zambaigos (virreinato del Perú siglo XVI)", pp.75-88. También ver: Alexandre Coello, "De mestizos y criollos en la Compañía de Jesús (Perú, siglos XVI-XVII)", en Revista de Indias vol.LXVIII, n. ${ }^{\circ} 243$, Madrid, Consejo Superior de Investigaciones Científicas, 2008, pp.37-66. Sobre las categorías "lobo" y "morisco" empleadas en Nueva España ver: B. Vinson III, "Moriscos y lobos en la Nueva España", pp.159178.

${ }^{50}$ Alejandra Araya, "Registrar a la plebe o el color de las castas: 'calidad', 'clase' y 'casta' en la Matrícula de Alday (Chile, siglo XVIII)", en Alejandra Araya y Jaime Valenzuela (eds.), América colonial. Denominaciones, clasificaciones e identidades, Santiago de Chile, Pontificia Universidad Católica de Chile/Universidad de Chile/Red Internacional del Libro, 2010, pp.331-362; "La Matrícula de Alday (1777-1778): imaginarios sociales y políticos en el siglo XVIII americano", en Grupo de Estudio de Historia de las Ciencias (eds.), Control social y objetivación: escrituras y tránsitos de las Ciencias en Chile, Santiago de Chile, Universidad de Chile, 2012, pp.15-33. 
das en otros censos como pardas. ${ }^{51}$ Esa relación entre mujeres, estado civil (viudas) y calidad también tiene un papel importante en el censo de 1765 de Curitiba al registrarse solo a las viudas notables como cabezas de familias, mientras que a las que carecían de prestancia se les registraron sin nombre y como cabeza de familia se anotaba el nombre del difunto. Esto quizá tenía que ver con la condición de sociedad de frontera de esta área del virreinato de Brasil y el peso prominente de la población masculina para efectos de la defensa militar. ${ }^{52}$

Roxana Boixadós y Judith Farberman han estudiado las diferencias registradas en los censos de 1767 y 1795 de la población de los Llanos (provincia de La Rioja, virreinato de La Plata), área que en el siglo XVIII transitaba de la condición de frontera aislada a estar integrada a la sociedad colonial mayor. Han sugerido que el significativo número de blancos registrados en el padrón de 1767 y su disminución en el de 1795, y a la inversa en el caso de los indios, se debía a que la condición de ser una sociedad de frontera y de una etapa inicial de apropiación de los recursos favoreció los procesos de blanqueamiento, pues en su mayoría se trataba de personas desarraigadas de sus pasados sociales y familiares. Pero cuando empezaron a perderse esas características y los padrones fueron desarrollados por personas civiles y eclesiásticas oriundas del lugar, se introdujeron modificaciones en las calificaciones que conllevaron a disminuir el número de blancos. En vista de esto, estas autoras califican al censo de 1795 como un intento por ordenar la sociedad de una manera conservadora, colocando trabas a la movilidad social mediante la aplicación de categorías socio-raciales más rígidas. En este tránsito, el conocimiento de la población desempeñó un papel determinante pues el censo de 1795 fue desarrollado por el cura de la comarca, oriundo de ese lugar y con acceso a la información pormenorizada sobre las genealogías de las personas. A esto achacan el incremento de las categorías del mestizaje, en especial las de mulato y mestizo, y la disminución de las categorías socio-raciales primarias como los blancos y los indios. ${ }^{53}$

\footnotetext{
51 María Meriño y Aisnara Perera, Familias, agregados y esclavos. Los padrones de vecinos de Santiago de Cuba (1778-1868), Santiago de Cuba, Eds. Oriente, 2011, pp.138-253.

${ }^{52} \mathrm{M}$. Andreazza, "El papel de los censos en la producción de las categorías sociales y espaciales de las colonias americanas", pp.117-135.

${ }^{53}$ Roxana Boixadós y Judith Farberman, "Una aproximación a la diversidad étnica y social en Los Llanos riojanos del siglo XVIII", en Judith Farberman y Silvia Ratto (coords.), Historias mestizas en el Tucumán colonial y las pampas (siglos XVII-XVIII), Buenos Aires, Ed. Biblos, 2009, pp.80-84.
} 
Para determinar los factores que incidieron en los cambios en las proporciones numéricas entre los diversos grupos, Boixadós y Farberman acuden a la reconstrucción de microbiografías de personas de distintas condiciones utilizando diversas fuentes de archivos para determinar si la riqueza, la pertenencia a redes sociales y ser antiguo o nuevo vecino favorecían la movilidad social expresada en el blanqueamiento. Ese recurso también lo consideran útil para establecer las posibles correlaciones y divergencias entre las calificaciones aplicadas por los empadronadores y lo que sucedía en la relaciones sociales. ${ }^{54}$

Pese a que este recurso de cruzar la información que contienen con la registrada en otras fuentes como la parroquial, notarial, judicial y de archivos locales ha demostrado ser muy eficiente para contrarrestar las deficiencias y vacíos presentes en los padrones de población, se reconoce que estas documentaciones también presentan problemas como es el caso de la eclesiástica. A propósito de un estudio sobre las clasificaciones socio-raciales en la población de Santa María, situada en el valle del río Calchaquí, en el nororiente del virreinato de La Plata, contrastando la información contenida en las actas de defunciones, bautismos y matrimonios y los libros de fábricas depositados en el archivo parroquial y los censos generales de 1771 y 1812, Lorena Rodríguez muestra las variaciones en los criterios de clasificación de las personas (indios y españoles en los libros de fábrica de entierros de comienzos del siglo XVIII; además de las anteriores el informe de un sacerdote de 1737 agregó la de mestizos, españoles, indios, mestizos, esclavos, pardos libres y sin identificar en libros de bautismos, matrimonios y defunciones de 1760 en adelante). La triangulación de la información le permite demostrar que a algunas personas se les asignaron distintas clasificaciones a lo largo de sus periplos vitales, y que muchos de los registrados en los libros parroquiales de españoles provenían de mezclas impuras pero que en una sociedad de mayoría indígena el mestizo podía ser asimilado al blanco. La explicación la encuentra en la rigidez adquirida por los criterios de clasificación a finales del XVIII con el fin de impedir la movilidad social y mantener el privilegio de los notables. Ese cerramiento fue resultado de menguar el peso de los factores de la ascendencia y los socio-culturales de la calidad de las personas, colocándose el énfasis en la apariencia física. ${ }^{55}$

\footnotetext{
${ }^{54}$ R. Boixadós y J. Farberman, “Una aproximación a la diversidad étnica y social en Los Llanos riojanos del siglo XVIII”, pp.79-114.

${ }^{55}$ Lorena Rodríguez, "Repensando las clasificaciones socio-étnicas del siglo XVIII. Indios, mestizos y españoles al sur del valle Calchaquí (Argentina)”, en Fronteras de la Historia vol.13, n. ${ }^{\circ}$, Bogotá,
} 


\section{Historiografía colombiana y censos de población}

En los cinco últimos decenios la historiografía sobre Colombia vio incrementar el uso de los distintos censos coloniales de población gracias tanto a los ensayos de reconstrucción de la demografía histórica de la población indígena, como también en los trabajos de compilaciones estadísticas. Los debates sobre el impacto de la conquista sobre aquella población, las encomiendas, resguardos y relaciones conflictivas con gentes de otras condiciones, como también acerca de los sistemas de tributación que les impusieron, acudieron a los informes de visitas de la tierra escritos por los funcionarios delegados por la Real Audiencia y a los listados de matrículas de los tributarios. 56

Además, las compilaciones estadísticas, como la de Fernando Gómez sobre los censos anteriores a 1905, colocó al alcance de los investigadores el resumen del padrón del Nuevo Reino de Granada de 1777-1780,57 empleado con alguna frecuen-

Instituto Colombiano de Antropología e Historia, 2008, pp.305-326.

${ }^{56}$ Entre los trabajos más significativos citamos: Jaime Jaramillo Uribe, "La población indígena de Colombia en el momento de la conquista y sus transformaciones posteriores", en Anuario Colombiano de Historia Social y de la Cultura n. ${ }^{\circ}$ 2, Bogotá, Universidad Nacional, 1964, pp.239-293; Juan Friede, "Algunas consideraciones sobre la evolución demográfica en la Provincia de Tunja”, en Anuario Colombiano de Historia Social y de la Cultura n. ${ }^{\circ}$, Bogotá, Universidad Nacional, 1965, pp.5-19; Germán Colmenares, Encomienda y población en la provincia de Pamplona, 1549-165o, Bogotá, Universidad de los Andes, 1969; La provincia de Tunja en el Nuevo Reino de Granada, Bogotá, Universidad de los Andes, 1970. María Ángeles Eugenio, Tributo y trabajo del indio en Nueva Granada (de Jiménez de Quesada a Sande), Madrid, Escuela de Estudios Hispano Americanos/Consejo Superior de Investigaciones Científicas, 1977, pp.123-223; Maríangeles Mingarro, Tributo y familia en la Nueva Granada. La provincia de Tunja en los siglos XVII y XVIII, Valencia, Universitat Jaume I, 2004, pp.71-117. Un balance en Hermes Tovar, "Estado actual de los estudios de demografía histórica en Colombia", en Anuario Colombiano de Historia Social y de la Cultura n. ${ }^{\circ} 5$, Bogotá, Universidad Nacional, 1970, pp.65-140. También ver Julián Ruiz, Fuentes para la demografía histórica de Nueva Granada, Sevilla, Escuela de Estudios Hispano Americanos, 1972; Encomienda y mita en Nueva Granada en el siglo XVII, Sevilla, Escuela de Estudios Hispano Americanos, 1975, pp.3-123. Una recapitulación reciente sobre la historiografía demográfica indígena relativa a la provincia de Tunja en J. Michael Francis, "Población, enfermedad y cambio demográfico, 1537-1636. Demografía histórica de Tunja: Una mirada crítica", en Fronteras de la Historia n. ${ }^{\circ} 7$, Bogotá, Instituto Colombiano de Antropología e Historia, 2002, pp.13-76. Para el caso de la provincia de Cartagena ver: Julián Ruiz, Los indios de Cartagena bajo la administración española en el siglo XVII, Bogotá, Archivo General de la Nación, 1996.

${ }^{57}$ Fernando Gómez, "Los censos en Colombia antes de 1905", en Miguel Urrutia y Mario Arrubla (comps.), Compendio de estadística histórica de Colombia, Bogotá, Universidad Nacional, 1970, pp.9-30. 
cia por la historiografía económica y social de los años 1970 y 1980. A esta siguió el esfuerzo más significativo que se ha realizado para ofrecer a los historiadores un trabajo de estadística de demografía histórica como el realizado por el equipo coordinado por Hermes Tovar Pinzón, el que reunió de forma pormenorizada y depurada cifras sobre los distintos censos del Nuevo Reino de Granada y la República de Colombia, comprendidos entre 1777 y 1830 . Esta compilación estadística está construida y organizada con base en los distintos resúmenes de los censos provinciales de 1777 en adelante, y sigue el patrón de las categorías que estos contienen, los que solo señalaron las condiciones de eclesiásticos, blancos, indios, libres de todos los colores y esclavos de varios colores. ${ }^{58}$ Por eso durante los últimos veinte años esta compilación se ha convertido en obra de obligatoria referencia.

Sin embargo, solo en fechas recientes el creciente empleo de los censos se acompaña con una progresiva preocupación por examinar, por ejemplo, los orígenes y la evolución de las categorías socio-raciales que contienen. Para ello se ha comenzado a explorar distintas fuentes de archivos, pues las dinámicas de esas categorías son difíciles de explorarse en los padrones. Los estudios se han focalizado en los Andes centrales (jurisdicciones de Santa Fe de Bogotá y Tunja), ${ }^{59}$ mientras que para el resto de las provincias neogranadinas solo se conoce algunos aspectos de las dinámicas de esas categorías en el siglo XVIII, ${ }^{60}$ permaneciendo en penum-

\footnotetext{
${ }^{58}$ Hermes Tovar, Camilo Tovar y Jorge Tovar, Convocatoria al poder del número. Censos y estadísticas de la Nueva Granada (1750-1830), Bogotá, Archivo General de la Nación, 1995.

${ }^{59}$ Sobre los orígenes eclesiásticos de algunas categorías socio-raciales en Santa Fe de Bogotá ver Juan Cobo, Mestizos heraldos de Dios. La ordenación de sacerdotes descendientes de españoles e indígenas en el Nuevo Reino de Granada y la racialización de la diferencia 1573-1590, Bogotá, Instituto Colombiano de Antropología e Historia, 2012, pp.101-126. Sobre los orígenes y dinámica de algunas categorías socio-raciales en esa ciudad ver: Joanne Rappaport, "'Asi lo paresçe por su aspeto': fisiognomía y construcción de la diferencia en la Bogotá colonial”, pp.13-42; "Buena sangre y hábitos españoles: repensando a Alonso de Silva y Diego de Torres", en Anuario Colombiano de Historia Social y de la Cultura vol.39, n. ${ }^{\circ}$, Bogotá, Universidad Nacional, 2012, pp.19-48; "El mestizo que desaparece: El género en la construcción de redes sociales entre mestizos de élite en Santafé de Bogotá, siglos XVI y XVII", en Juan Escobar, Sarah de Mojica y Adolfo Maya (eds.), Celebraciones y crisis: Procesos independentistas en Iberoamérica y la Nueva Granada, Bogotá, Universidad Javeriana, 2012, pp.365-386; "¿Quién es mestizo? Descifrando la mezcla racial en el Nuevo Reino de Granada, siglos XVI y XVII", pp.43-6o. Marta Zambrano, "Ilegitimidad, cruce de sangre y desigualdad: dilemas del porvenir en Santa Fe colonial", en N. Böttcher, B. Hausberger y M. Hering Torres, El peso de la sangre. Limpios, mestizos y nobles en el mundo hispánico, pp.251-281.

${ }^{60}$ Hermes Tovar, La estación del miedo o la desolación dispersa. El Caribe colombiano en el siglo XVI, Bogotá, Ariel, 1997; Steinar Saether, Identidades e independencia en Santa Marta y Riohacha, 1750-1850, Bogotá, Instituto Colombiano de Antropología e Historia, 2005; Aline Helg, Libertad e
} 
bras lo sucedido en los siglos XVI y XVII, ${ }^{61}$ excepto para las poblaciones de indios y los negros esclavos, libres y cimarrones que cuentan con algunos trabajos significativos. ${ }^{62}$

Sin embargo, estudios más puntuales sobre los censos muestran unas realidades no perceptibles en los resúmenes. Por ejemplo, para las provincias del Caribe neogranadino en un reciente artículo Steinar Saether se preocupa por estudiar la presencia de los indios en los censos del siglo XVIII, insistiendo en las dificultades que enfrentaron los empadronadores al momento de definirlos dada la inclinación de aquellos a eludir el pago del tributo, presentándose como mestizos. Pero así mismo ha llamado la atención sobre las prerrogativas que otorgaba ser clasificado como tal, en especial el tener un status especial que le consagraba el acceso a las tierras de los resguardos y a un status especial dentro del orden colonial, del que carecían los mestizos. ${ }^{63}$

Para el último siglo de dominación colonial Katherine Bonil elaboró el único trabajo que ha analizado las categorías de clasificación social de un área neograna-

igualdad en el Caribe colombiano 1770-1835, Medellín, Eafit/Banco de la República, 2011, pp.151218.

${ }^{61}$ Para el caso de la provincia de Popayán ver: Germán Colmenares, Popayán una sociedad esclavista, 1680-18oo, Medellín, La Carreta Eds., 1979; Peter Marzahl, Una ciudad en el Imperio. El gobierno, la política y la sociedad de Popayán en el siglo XVII, Popayán, Universidad del Cauca, 2013, pp.67-89; Diego Romero, Poblamiento y sociedad en el Pacífico colombiano siglos XVI al XVIII, Cali, Universidad del Valle, 1995. Para Santa Fe de Bogotá ver: Marta Zambrano, Trabajadores, villanos y amantes: encuentros entre indígenas y españoles en la ciudad letrada. Santa Fe de Bogotá (1550-1650), Bogotá, Instituto Colombiano de Antropología e Historia, 2008.

62 Para el caso de las provincias de Santa Marta, Riohacha y Cartagena, situadas en el Caribe neogranadino ver: Julián Ruiz, Los indios de Cartagena bajo la administración española en el siglo XVII, Bogotá, Archivo General de la Nación, 1996; "Gobierno, comercio y sociedad en Cartagena de Indias en el siglo XVII”, en Adolfo Meisel y Haroldo Calvo (eds.), Cartagena de Indias en el siglo XVII, Cartagena, Banco de la República, 2007, pp.354-376; Marta Herrera, "El poblamiento en el siglo XVI y principios del XVII. Contrastes entre el Caribe y el interior andino", en Haroldo Calvo y Adolfo Meisel (eds.), Cartagena de Indias en el siglo XVI, Cartagena, Banco de la República, 2010, pp.203-237. También ver otros ensayos compilados en este libro y en Haroldo Calvo y Adolfo Meisel (eds.), Cartagena de Indias en el siglo XVII, Cartagena, Banco de la República, 2007. María Borrego, Cartagena de Indias. La andadura de una vida bajo la Colonia, Bogotá, El Áncora Eds., 2010, pp.23-72, 191-299; María C. Navarrete, Génesis y desarrollo de la esclavitud en Colombia siglos XVI y XVII, Cali, Universidad del Valle, 2012.

${ }^{63}$ S. Saether, "Counting indians: census categories in late colonial and early republican Spanish America”, pp.60-63. 
dina (la provincia de Mariquita) cruzando los resúmenes de censos de esa provincia con otras informaciones como los expedientes judiciales. Su interés se ha centrado en develar las relaciones entre el poder y las clasificaciones sociales, por lo que se ha interesado en quién enuncia, quiénes son cobijados por las clasificaciones, cómo estas podían ser instrumentalizarlas de acuerdo a las conveniencias de los distintos actores sociales y las relaciones entre las categorías y las prácticas sociales. Señala la existencia de una diversidad de términos cuyo empleo dependerá de los contextos locales y comarcanos, y diferencia entre las intenciones de los altos poderes y las labores de los empadronadores que muchas veces negociaban con los censados el empleo de las clasificaciones. ${ }^{64}$

Por estas y por otras razones se empiezan a suscitar un debate sobre las formas clasificatorias contenidas en los padrones de 1778 en adelante. Ahora hay interés por ir más allá del uso de las cifras y de las clasificaciones que ofrecen los resúmenes de ese censo, y se ha iniciado un debate sobre las implicaciones metodológicas e historiográficas que tiene el uso de las categorías agregadas. Marta Herrera es la historiadora que más lejos ha ido en las advertencias sobre el cuidado que debe tenerse al emplear los censos del último cuarto del siglo XVIII, señalando varios aspectos de mucha importancia para los propósitos de este libro. En sus estudios sobre los procesos de poblamiento y el ordenamiento espacial y social del Nuevo Reino de Granada, ha sido la pionera en proponer un cuestionamiento a las categorías socio-raciales registradas en la documentación oficial de ese entonces. Categorías como "chimilas", "españoles", ${ }^{65}$ "arrochelados" 66 y "libres de todos los colores" 67 han concentrado la atención de esta historiadora, quien mediante una reducción de la escala de análisis en la que conjuga recursos de archivos del orden provincial, comarcano, y local como también conflictos individuales, propone que exis-

\footnotetext{
${ }^{64}$ Katherine Bonil, Gobierno y calidad en el orden social. Las categorías del mestizaje en la provincia de Mariquita en la segunda mitad del siglo XVIII, Bogotá, Universidad de los Andes, 2011, pp.139-167.

65 Marta Herrera, “'Chimilas' y 'españoles': el manejo político de los estereotipos raciales en la sociedad neogranadina del siglo XVIII”, en Memoria y Sociedad vol.7, n. ${ }^{\circ} 13$, Bogotá, Universidad Javeriana, 2002, pp.5-24.

${ }_{66}$ Marta Herrera, "El arrochelamiento: nominar para criminalizar", en El Taller de la Historia n. $^{\circ}$, Cartagena, Universidad de Cartagena, 2010, pp.11-46.

${ }^{67}$ Marta Herrera, "Libres de todos los colores el ordenamiento social en las llanuras del Caribe, siglo XVIII”, en Alberto Abello (comp.), El Caribe en la nación colombiana (Memorias), Bogotá, Museo Nacional de Colombia/Observatorio del Caribe Colombiano, 2006, pp.248-267.
} 
tieron tendencias contradictorias en los sistemas de clasificación. Por una parte unas categorías generalizantes ("libres de todos los colores") que obedecieron a un interés de las autoridades en tener una comprensión de conjunto de la sociedad. Por otra parte categorías particulares (blanco, negro, indio, zambo, mulato y otras) que tenían como propósito fraccionar a los habitantes de una población adscribiéndoles identidades distintas, operación que se repitió hasta con los miembros de unas mismas familias que social y culturalmente compartían el mismo mundo social y cultural. ${ }^{68}$ Para demostrar sus argumentos M. Herrera hace un seguimiento a las circunstancias que habían llevado a un crecimiento significativo de los libres para la segunda mitad de ese siglo, resaltando la importancia que adquirió la libertad entre sectores de las gentes de color con relación a la población esclava y a los indios tributarios.

De igual forma Alfonso Múnera ha advertido que los estudios del censo han servido para respaldar la imagen excluyente de una nación mestiza construida del siglo XIX en adelante, en especial la categoría "libres de todos los colores" que desconocía la existencia de una población negra libre e indígena. Considera que al asociar esa categoría al mestizaje los historiadores terminan justificando una imagen de una nación en la que los problemas étnicos no existían. ${ }^{69}$

Pero otros historiadores han respaldado el empleo de las categorías de los resúmenes desde dos perspectivas. Una está arraigada en una especie de la relación política presente-pasado que extiende los hechos políticos de la actualidad al estudio de la historia, arrastrando en muchas ocasiones errores de anacronismos. Y la otra tiene que ver con la reciente historiografía política y de las reconsideraciones introducidas por los nuevos estudios sobre las reformas borbónicas.

Algunas variantes de la primera perspectiva son frutos de la combinación entre los actuales procesos de reinvención de las identidades de las gentes de color y de la aplicación del modelo de la sociedad racial estadounidense a los estudios del pasado neogranadino. Para estas miradas las categorías aglutinantes de los resúmenes de los censos de 1777 en adelante le vienen como anillo al dedo, pues sirven para apuntalar la imagen de una comunidad organizada en torno a la condición racial negra (o parda), no fraccionada, con un imaginario ligado a un hipotético

${ }^{68}$ M. Herrera, "Libres de todos los colores el ordenamiento social en las llanuras del Caribe, siglo XVIII”, pp.252, 259.

${ }^{69}$ A. Múnera, Fronteras imaginadas, pp.129-152. 
punto de partida de la diáspora (África), y un proyecto colectivo de liberación en el que todos participaban. Por eso, las categorías como las de "libres de todos los colores" y "pardos" se trastocan rápidamente en las de "afrodescendientes" y "negros".70

No cabe duda que se conservaron elementos de las culturas de sus lugares de orígenes, pero como bien lo ha señalado Patrick J. Carroll a propósito de los negros del puerto de Veracruz, debe distinguirse entre la etiqueta racial asignada y la etnia (las expresiones culturales de origen africano que los identificaban), cuyas relaciones fueron desiguales y se inclinaron a favor de la raza en detrimento de lo étnico. ${ }^{71}$ Con base en estudios de casos de esclavos que compartieron periplos vitales desde que fueron apresados en sus lugares de origen, los que luego se prolongaron en las colonias españolas y portuguesas, Herbert S. Klein y Ben Vinson III han planteado que pese a la diversidad de los orígenes de los esclavos se formación identidades, las que sin embargo, no eran réplicas exactas de las de los lugares de orígenes, y mucho menos una supuesta identidad africana. ${ }^{72}$ Quiere esto decir que hubo un

70 Una crítica a estas imágenes anacrónicas en Antonio García de León, Tierra adentro, mar en fuera. El puerto de Veracruz y su litoral a Sotavento, 1519-1821, México D. F., Fondo de Cultura Económica/Gobierno del Estado de Veracruz/Universidad Veracruzana, 2011, pp.536-555. Para el caso colombiano una crítica a la categoría de "afrodescendientes" en S. Saether, "Estudios recientes sobre raza e independencia en el Caribe colombiano (1750-1835)”, pp.382-383. A propósito de los negros de Cuba un estudio reciente afirma: "El continente africano, en su conjunto, no puede ser admitido como un referente generalizador para los hombres esclavizados que fueron arrojados masivamente al Nuevo Mundo. Pocos habían traspasado el territorio de su etnias, las lenguas que hablaban era diversas, también lo eran sus características físicas, sus sistemas religiosos y su organización política. Los sistemas de parentesco no constituyeron una excepción en esa diversidad [...]”. María Barcia, La otra familia. Parientes, redes y descendencia de los esclavos en Cuba, Santiago de Cuba, Ed. Oriente, 2009, p.68. Carmen Bernand se ha preguntado hasta dónde sobrevivieron las "naciones" de los esclavos traídos de África, y ha resaltado lo que ella llama "el proceso de ladinización". Negros, esclavos y libres en las ciudades hispanoamericanas, Madrid, Fundación Larramendi, 2000, pp.39-68. http://goo.gl/XKQDed. Testamentos del siglo XVIII de negros y pardos esclavos y libres evidencian hasta dónde había avanzado el proceso de mestización cultural. Ver: Orián Jiménez y Edgardo Pérez (comps.), Voces de esclavitud y libertad. Documentos y testimonios. Colombia 1701-1833, Popayán, Universidad del Cauca, 2013, pp.37-16o. Pese a que emplea la categoría de "afrolatinoamericano", George Reid Andrews muestra el mestizaje que vivieron los descendientes de los negros traídos de distintos puntos de África. Afrolatinoamérica 1800-200o, Madrid/Frankfurt, Iberoamericana/Vervuert, 2007, pp.46-94.

${ }^{71}$ Patrick J. Carroll, "Perfiles demográficos y culturales esquemáticos en la comunidad de esclavos del centro de Veracruz dentro de un contexto interpretativo más amplio", en Signos Históricos vol.II, n. ${ }^{\circ}$ 4, México D. F., Universidad Autónoma Metropolitana-Iztapalapa, 2000, pp.58-59.

${ }^{72}$ Herbert S. Klein y Ben Vinson III, La esclavitud en América Latina y el Caribe, México D. F., El Colegio de México, 2013, pp.176-210. 
intenso proceso de mestizaje cultural entre la población descendientes de los esclavizados, ya continuasen bajo esa condición ya fueran libres, generándose una jerarquía diferenciada basada en el color de la piel.

De igual forma debe tenerse en cuenta que recientemente la historiografía estadounidense viene debatiendo acerca de la construcción de los discursos raciales en ese país. Sectores de historiadores de ese país argumentan que la representación racial bipolar de la sociedad del sur estadounidense ("blancos" y "negros") solo se introdujo en el último cuarto del siglo XIX mediante la supresión de una gama de categorías sociales previas situadas entre aquellos extremos. De forma más detallada la situación empezó a cambiar una vez culminó la guerra civil (1861-1865) que al tiempo que originó el fin de las diferencias entre esclavos y personas libres de color, y la prohibición de matrimonios entre desiguales, también introdujo la ideología de "una gota de sangre" en los antepasados para definir a una persona como negra. Diversidades socio-raciales también se reconocían en el Surinam holandés y en Jamaica. ${ }^{73}$

La segunda perspectiva ha sido defendida en la historiografía reciente por varios historiadores y desde modelo distintos. Según Margarita Garrido el origen del concepto "libres de todos los colores" estuvo ligado a la extensión del mestizaje, a las formas de poblamiento por fuera del control de las autoridades coloniales y a la reforma militar de 1773. Para esta historiadora la conjunción de estos tres elementos abrió fisuras en el orden colonial basado en criterios raciales y permitió espacios para la participación política de los sectores subalternos, en especial de aquellos que empezaron a reclamar reconocimiento social gracias a la construcción de un estilo de vida basado en el positivo esfuerzo personal y en el honor. Sin embargo, estas aspiraciones chocaron con los obstáculos que les imponía la condición socio-racial. A finales de la Colonia esto produjo, y esta es una de las ideas más interesantes del análisis de esta historiadora, la no correspondencia entre el ordenamiento racial y el político. ${ }^{74}$ En sus luchas por construirse una imagen individual y

\footnotetext{
73 A. Twinam, "American Defects:" Pardos, mulatos and the quest for whiteness in the Spanish Indies. También ver a Catharine Good, "Reflexiones sobre la raza y el racismo; el problema de los negros, los indios, el nacionalismo y la modernidad”, en Dimensión Antropológica n. ${ }^{\circ}$ 14, México D. F., Instituto Nacional de Antropología e Historia, 1999. http://goo.gl/6gLMI4.

${ }^{74}$ Margarita Garrido, "Libres de todos los colores en Nueva Granada. Identidad y obediencia antes de la Independencia", en Nils Jacobsen y Cristóbal Aljovín (coords.), Cultura política en los Andes, Lima, Universidad Nacional Mayor de San Marcos/Instituto Francés de Estudios Andinos, 2007, pp.245-266.
} 
familiar respetable, muchos de estos libres de todos los colores "[...] destituidos de pertenencias étnicas claras [...]" ligaron sus imágenes al sitio de vivienda y en consecuencia actuaron como vecinos. ${ }^{75}$

Otros estudiosos del pasado defienden el uso de la categoría "libres de todos los colores" y la generalización del término "pardo" para denominar a todos los libres que por una de sus líneas ascendientes tuviesen antepasados negros, resaltando las connotaciones políticas de ambas categorías. El modelo que sustenta esta interpretación parte de considerar que durante la Colonia los grupos sociales eran creaciones políticas en la medida que la monarquía española definía y reglamentaba su existencia y su orden jerárquico (estamentos de blancos e indios). Al lado de estos estaban las castas originadas en el mestizaje y cuyas existencias no tenían definiciones legales precisas como si la tenían aquellos. Tanto el mestizaje como las necesidades de la monarquía llevaron a que a finales del siglo XVIII los blancos pobres, indios y mestizos fueran redefinidos como el "estado llano" o la "plebe" y que se les otorgara el derecho a participar en las decisiones públicas, indistintamente de la condición socio-racial. ${ }^{76}$ Consideran que esa redefinición de los actores sociales y político en buena medida se facilitó y se expresó en el fortalecimiento de la categoría del vecino, pues en una sociedad de orden corporativo esa condición era clave para la participación en la vida política de las poblaciones. El libre radicado de forma estable en una población quedaba integrado en esa condición política, con sus derechos y deberes. Y en esto cabían blancos, mestizos, mulatos y todas las demás mixturas. ${ }^{77}$

Armando Martínez ha sugerido que con las reformas militares borbónicas culminó el proceso de integración de las gentes de color a la sociedad colonial y los términos "pardo" y "moreno" "[...] pasaron de describir una condición racial a asignar un estatus de miliciano y servidor de la monarquía”, logrando algunos privile-

\footnotetext{
75 Margarita Garrido, "Honor, reconocimiento, libertad y desacato: sociedad e individuo desde un pasado cercano", en Luz G. Arango, Gabriel Restrepo y Carlos E. Jaramillo (eds.), Cultura, política y modernidad, Bogotá, Universidad Nacional, 1998, pp.99-121.

${ }^{76}$ Claudia Guarisco, "El reformismo borbónico y la participación política de indios y estado llano en el Valle de México" en Jahrbuch für Geschichte Lateinamerikas n $^{\circ} 40$, Viena, Universität Graz, 2003, pp.97-121.

77 Jorge Conde y Edwin Monsalvo, "Las clases del pueblo en ebullición. Pardos y mulatos en la independencia de Cartagena 1809-1815", en Amauta n. ${ }^{\circ}$ 19, Barranquilla, Universidad del Atlántico, 2012, pp.33-49.
} 
gios como el fuero militar. En consecuencia, muchas de las divisiones de las calidades sociales de las personas (quinterón, cuarterón, zambo, mestizo, mulato) dejaron de funcionar como categorías políticas y terminaron englobadas en conceptos como blancos, pardos, indios, morenos y negros, gracias a los acentos que les otorgaron los encuadramientos institucionales como la incorporación de esos sectores a la doble condición de vecinos y milicianos.

Esta idea descansa en tres reconsideraciones historiográficas elaboradas en los últimos años. La primera es que la sociedad de la Colonia tardía era de órdenes basada en privilegios representados en los fueros, lo que permite entender tanto la existencia de la condición política del vecino, como de una movilidad social de la que estaría exenta una sociedad organizada por castas. La segunda es que para ese periodo y gracias al encuadramiento institucional de los pardos, el color de la piel perdió peso en las formas de discriminación, basándose esta en la bastardía y en sus implicaciones morales. Y la tercera es que cabalgando sobre una realidad social en la que el mestizaje hacía difusas las fronteras entre algunos grupos de gentes de color, la Monarquía definió ciertos privilegios a estos e intentó integrar a los libres de color en una categoría política agregada como la de los "pardos". 78

Entre las interpretaciones que hemos comentado es la de Jorge Conde la que más se ha esforzado en integrar muchos de los aspectos que están en discusión (raza, clase, novedades políticas que trajeron las reformas borbónicas) y los ha propuesto como elementos claves para entender la vida política colombiana de la primera mitad del siglo XIX. En efecto, la perspectiva del análisis de este historiador es más compleja dado que a pesar de interesarse en las modificaciones políticas que se fueron escenificando durante los años de la crisis del imperio español (de 1808 en adelante) y durante los primeros decenios de la República, reconoce la existencia de una compleja variedad socio-racial durante el siglo XviII: "[...] entre las de mayor empleo en el lenguaje de la época fueron: Pardo: mestizo con una gota de sangre negra; zambo: mestizo de negro y de indio; mulato, grifo, tercerón, cuarterón, quinterón, salto atrás; los mestizos de pardo y negro tenían diversos grados: moreno, eufemismo de pardo". ${ }^{79}$ Según el historiador que estamos comentando esa

\footnotetext{
78 Armando Martínez, "Arrabal, prejuicio moral y demanda de instrucción: elementos para comprender el estatus de los caballeros pardos en la transición a la sociedad republicana", en Historia Caribe vol.vi, n. ${ }^{\circ}$ 19, Barranquilla, Universidad del Atlántico, 2011, pp.13-41.

${ }^{79}$ J. Conde, Buscando la nación. Ciudadanía, clase y tensión racial en el Caribe colombiano, 18211855, pp.17, 35. Énfasis en el original. En otro libro este historiador había explorado algunos censos
} 
diversidad, que la ubica como uno de los obstáculos en el proceso de formación de la nación, tenía su mayor riqueza en las provincias del Caribe neogranadino, "[...] de tal manera que las autoridades tenían que utilizar la expresión libres de todos los colores para disipar las confusiones que generaban, de manera recurrente, el carácter mixto de los fenotipos y de los estatus". ${ }^{80}$

Con base en ese reconocimiento como aspectos claves para entender la vida política de la primera mitad del siglo XIX, este autor ha argumentado en parecida dirección a la de Armando Martínez al anotar que las reformas borbónicas facilitaron a las gentes libres nuevas formas de participación política, y pese a las diferencias socio-raciales, laborales y de prestancia, las integraron en el estatuto político del "estado llano" y "plebe", generándose conflictos con los notables de las poblaciones que vieron amenazados sus privilegios. Para finales de la Colonia, pardos y mulatos habían asimilado los valores de los notables y "[...] constituían una subdivisión o calidad del estamento español”. Los factores institucionales que marcaron estas novedades fueron la condición de vecinos que generaba espacios para la participación política y la de milicianos. ${ }^{81}$

Pues bien, tanto las preocupaciones historiográficas de Marta Herrera y Alfonso Múnera, como las de Armando Martínez y Jorge Conde son de interés por dos razones. 1) Porque obligan a estudiar la genealogía del censo de 1777, y a deconstruir las categorías aglutinantes para ahondar en los propósitos de las administraciones coloniales que las echaron a andar, y analizar los procesos de apropiaciones y resignificaciones de que fueron objetos por parte de distintos sectores sociales. 2) Porque la redefinición del estatuto político de los sectores bajos permite entender algunas transformaciones en la esfera de las relaciones entre los individuos,

de 1777 y de igual forma había resaltado la presencia de una diversidad de categorías como las que estudiamos en este libro. Espacio, sociedad y conflictos en la provincia de Cartagena 1740-1815, Barranquilla, Universidad del Atlántico, 1999, pp.87-116.

80 J. Conde, Buscando la nación. Ciudadanía, clase y tensión racial en el Caribe colombiano, 18211855, p.35.

${ }^{81}$ Jorge Conde, "Los xefes de los pardos: la consolidación de un sector social intermedio durante la independencia de Cartagena de Indias", en Historia y Sociedad n. ${ }^{\circ} 23$, Medellín, Universidad Nacional, 2012, pp.151-153; Buscando la nación. Ciudadanía, clase y tensión racial en el Caribe colombiano, 1821-1855, p.32. Sobre el concepto de "plebe" en el siglo XVIII ver: Roland Anrup y María E. Chaves, "La 'plebe' en una sociedad de 'todos los colores'. La construcción de un imaginario social y político en la colonia tardía en Cartagena y Guayaquil", en Caravelle n. ${ }^{\circ} 84$, Toulouse, Universidad de Toulouse, 2005, pp.93-126. 
sus familias y la Monarquía y sus instituciones, y el papel de los primeros en los entornos políticos locales. También garantiza situar en un plano muy distinto la dinámica social y política de finales del siglo XVIII, en especial el estudio de la dialéctica entre el conflicto y la integración social, frente a una tradicional mirada historiográfica solo atenida a criterios "raciales".

Sin embargo, esta última posibilidad demanda estar alerta para que el estudio de los procesos de mayor integración a la sociedad colonial y los logros en materia de reconocimiento por parte de las gentes libres de color no se haga con el único propósito de explicar la participación de estos sectores en la crisis política que se abrió de 1808 en adelante. Este solo énfasis corre el riesgo de suponer que desaparecieron los llamados factores socio-raciales que ordenaban y jerarquizaban a la sociedad, y que bajo el dominio de los borbones se dio una ruptura tajante con las taxonomías socio-raciales que le precedían. ${ }^{82}$ También se puede confundir las intenciones de las autoridades del periodo borbónico con lo que sucedía en las relaciones cotidianas entre las gentes. De igual forma se puede terminar presidario de lo que la información oficial nos dice a propósito de un tema sobre el que la experiencia historiográfica latinoamericana ha llamado a tener unas miradas desde distintos ángulos, y a tomar en cuenta los diferentes campos relacionales de las personas. De igual forma se confunde las relaciones de los individuos con las instituciones con el conjunto de las relaciones sociales.

\section{A manera de conclusión: posibles caminos a seguir}

Muchas de las deficiencias que acusan los análisis sobre la sociedad del siglo XVIII que tienen como fuentes de información a los censos de población se deben al desconocimiento de tres aspectos claves con relación a los datos que estos contienen.

El primero es el recurrente desconocimiento de que los resultados de los censos se presentaron en varios niveles (padrones de poblaciones llenos de muchos

\footnotetext{
82 Para una afirmación en esta dirección ver Luiz Geraldo Silva, "Negros de Cartagena y Pernambuco en la era de las revoluciones atlánticas: trayectorias y estructuras (1750-1840)", en Anuario Colombiano de Historia Social y de la Cultura vol.40, n. ${ }^{\circ}$ 2, Bogotá, Universidad Nacional, 2013, pp.211-240. Para un punto de vista crítico de las políticas sociales de los borbones ver: Ann Twinam, "Repensando las reformas sociales de los borbones en las colonias, siglo XVIII", en El Taller de la Historia vol.5, n. ${ }^{\circ}$, Cartagena, Universidad de Cartagena, 2013, pp.5-32.
} 
detalles; y resúmenes por partidos, provincias, virreinatos, intendencias y capitanías). 83

El segundo aspecto es que se desconoce que las iniciativas asumidas por la Corona española para contabilizar a la población de la metrópoli y de sus dominios de América y las Filipinas, estuvieron acompañadas por una tendencia a la simplificación en la presentación de los resultados por parte de las autoridades centrales de los virreinatos, lo que a su vez era expresión del pensamiento ilustrado.

Y el tercero es que el contraste entre los padrones de las poblaciones (al menos los de los censos de 1777 para los casos del Nuevo Reino de Granada y Nueva España) y los resúmenes nos dicen muchas cosas que por lo regular no aparecen en los estudios que solo se atienen a estos últimos compendios.

En efecto, en 1768 se realizó el censo de España conocido como el del Conde de Aranda, y en 1787 y 1797 se llevaron a cabo los censos del conde de Floridablanca y el del ministro Godoy respectivamente. De igual forma, durante el último cuarto de ese siglo las iniciativas de empadronar a la población se replicaron en los dominios españoles de América y Filipinas, realizándose varios censos con base en la orden real emitida en noviembre de 1776.

Los censos de población de las colonias no se pueden concebir de forma aisladas de los que se realizaban en España. El censo de 1768 del Conde de Aranda (de nuestro interés por su cercanía con la real orden de 1776 que mandaba a censar a los habitantes de las colonias) representó una transición entre las formas tradicionales de contabilizar a la población y las formas modernas. El mandato que conminaba a las autoridades ordinarias y eclesiásticas a levantarlo exigía que no se anotaran nombres para evitar sospechas por parte de los empadronados. Se suprimieron los registros de categorías sociales y empezó a dársele mayor énfasis a las ocupaciones. Solo contabilizó a los vecinos (cabeza de familia con casa poblada y residencia en una población), y se añadieron cifras sobre las consortes, hijos y agregados. ${ }^{84}$ El censo del conde de Floridablanca fue realizado y publicado en $1787,{ }^{85}$ siendo co-

\footnotetext{
${ }^{83}$ El censo de Nueva España de 1777 también posee esos niveles de presentación de los resultados. Ver: E. Sánchez, Padrón del Arzobispado de México de 1777, pp.33-35.

${ }^{84}$ Censo de Aranda, tomo I, Madrid, Real Academia de la Historia/Instituto Nacional de Estadística, 1991, p.13. (Edición facsimilar). http://goo.gl/Sjg39W.

${ }^{85}$ Censo español executado de Orden del Rey, comunicada por el Excelentísimo Señor Conde de Floridablanca, Primer Secretario del Estado y del Despacho, en el año de 1787, Madrid, Imprenta
} 
nocido por el conde de Revillagigedo, virrey de Nueva España, quien lo tomó como modelo del censo de este virreinato de 1791.86

Vista de conjunto se trataba de una política unitaria a pesar de que la aplicación y los resultados de los padrones asumieron diversas características acorde con las sociedades que se empadronaron. Productos de la mentalidad ilustrada, los censos de población y las relaciones geográficas aspiraban a que la corona y sus funcionarios tuvieran el conocimiento y las herramientas necesarias para el buen gobierno y la defensa del imperio, ampliar la esfera del Estado, impulsar la iniciativa privada y desvertebrar viejos privilegios. ${ }^{87}$ Por eso, cuando se estudian de conjunto se observa las transformaciones que se operaron con relación a los censos que les precedieron, como también una tendencia a su continua modernización expresada en una creciente universalidad y abstracción en las formas de recoger y de presentar los resultados, dejando de lado la gran cantidad de especificaciones de las distintas condiciones de los habitantes, las que sí estuvieron presentes en los censos anteriores. ${ }^{88}$

Esta era la experiencia relativa a censos conocida por los ilustrados que estaban al frente de los distintos virreinatos, capitanía, intendencias y provincias hispanoamericanas. Y a ellos les correspondió levantar los padrones ordenados por disposición real fechada el 10 de noviembre de 1776. Por ejemplo, Antonio de Ulloa, cercano al conde de Aranda, había participado en la organización del censo español

Real, 1787. http://goo.gl/nkJqIt. Este es el resumen general presentado por intendencias y provincias.

86 Áurea Commons, "La población de Nueva España en 1790”, p.10.

87 Juan Marchena, "Su Majestad quiere saber. Información oficial y reformismo borbónico en la América de la Ilustración” en Diana Soto, Miguel Puig, Martina Bender y María González (eds.), Recepción y difusión de textos ilustrados. Intercambio científico entre Europa y América en la Ilustración, Madrid, Rudecolombia/Colciencias/Universidad Pedagógica y Tecnológica de Colombia/Universidad de León/Doce Calles, 2003, pp.151-185.

${ }^{88}$ Eduardo García, “Censos de población españoles”, en Estadística Española n. ${ }^{\circ} 128$, Madrid, Instituto Nacional de Estadística, 1991, pp.441-500; M. Ardit, M. A. Badenes y J. S. Bernat, El pais Valencià en el cens d'Aranda (1768), Valencia, Universitat València, 2001, pp.13-44; Juan Hernández, "La realización del censo de Floridablanca en el corregimiento de Murcia", en Studia Historica: Historia Moderna n. ${ }^{\circ}$ 5, Salamanca, Universidad de Salamanca, 1987, pp.285-297; Vicente Pérez, "La estadística demográfica en el gobierno de la España ilustrada: recuerdo y elogio del Censo de Floridablanca”, en Índice n. ${ }^{\circ}$ 43, Madrid, Instituto Nacional de Estadística/Universidad Autónoma de Madrid, 2010, pp.8-17. 
de 1768 y luego diseñó los formatos para realizar el censo de Nueva España de 1777.89

3) Todo el interés se ha depositado en los resúmenes generales desconociéndose que estos obedecieron a un interés de la Monarquía y de sus funcionarios ilustrados para tener una visión de conjunto de la población bajo su jurisdicción. El no tener presente estos hechos lleva a que la imagen elaborada por los estudiosos de la sociedad neogranadina del siglo XVIII usualmente quede reducida a "eclesiásticos, blancos, indios, libre de todos los colores y esclavos de varios colores", tal como se presenta en el resumen general para el virreinato. Igual sucede para el caso de Puerto Rico, como se puede apreciar en un reciente artículo de Francisco Scarano y Katherine Curtis fundado en los resúmenes de los censos de 1779 a 1802. ${ }^{90}$

De igual forma, el uso de los resúmenes de los censos se da sobre la base del escaso conocimiento que se tiene acerca de cómo se llevaron a cabo los distintos empadronamientos, las técnicas empleadas para recoger la información, cómo se aplicaban las categorías socio-raciales a las personas, el papel de los empadronadores en la recopilación de los datos, las relaciones entre estos y los empadronados al momento de determinar en qué categoría quedaban adscritos estos últimos, y los mecanismos a los que se acudía para resolver las dudas. Esos y muchos otros aspectos son de vital importancia para evaluar tanto la utilidad de estos documentos como su valor como parte de un discurso sobre la estratificación de la sociedad colonial.

Como puede observar el lector, los anteriores argumentos remiten al tema de las relaciones entre el orden social existente a finales del siglo XVIII y las representaciones sociales construidas por el discurso ilustrado, en especial las relaciones entre viejas y nuevas categorías de diferenciación y la realidad social. El estudio de estas relaciones implica abordar cuatro aspectos diferenciados y a la vez comple-

${ }^{89}$ C. Casteñeda y L. Gómez, "La población de Guadalajara de acuerdo con el padrón militar de 1791 y el censo de la intendencia de 1793", p.45.

${ }^{90}$ K. Curtis and F. Scarano, "Puerto Rico’s population padrones, 1779-1802", pp.200-213. Los resúmenes de esos censos están en: 1779: Archivo General de Indias (AGI), Santo Domingo 2302; 1780 y 1781: AGI, Indiferente General 1527; 1782, 1783, 1784, 1785: AGI, Santo Domingo 2302; 1786: AGI, Santo Domingo 2483; 1787 AGI, Indiferente General 1527; 1788, 1789, 1790, 1791: AGI, Santo Domingo 2309; 1792: AGI, Santo Domingo 2288; 1793: AGI, Santo Domingo 2309; 1794: AGI, Santo Domingo 2313; 1795 AGI, Santo Domingo 2315; 1797: AGI, Santo Domingo 2288; 1798 AGI, Santo Domingo 2318; 1799, 1800, 1801: AGI, Santo Domingo 2288. Y pueden leerse y bajarse de la Madison Library de la University of Wisconsin. http://www.disc.wisc.edu/archive/padrones/index.html. 
mentarios. El primero es el papel de las instituciones y de los discursos oficiales en la producción del orden social. El segundo son los procesos de construcción de los documentos que crean, reafirman o modifican las representaciones sociales, tarea lamentablemente desdeñada por la mayoría de los historiadores pese a que reconocen que aquellos constituyen buena parte de la materia prima con la que construyen sus análisis. El tercero se refiere a la necesidad de contrastar esas construcciones discursivas con las prácticas sociales de las gentes en sus vidas cotidianas. $\mathrm{Y}$ el cuarto obliga a establecer qué sobrevivía de las anteriores formas de representación social, su presencia en los documentos, y hasta dónde pueden sesgar la observación del historiador y llevarlo, tanto a desconocer las nuevas realidades que estaban emergiendo como a creer que estas automáticamente borraban viejas clasificaciones.

Esta agenda de investigación obliga a centrar las reflexiones en el papel que le asignamos a las prácticas sociales, a las representaciones y a las funciones de las instituciones y de la escritura en la producción de aquellas y del orden social. Al respecto Roger Chartier ha planteado que las respuestas a temas como los contemplados en esa agenda no pueden provenir de un viejo modelo histórico-filosófico que solo vio quiebres entre el discurso ilustrado por un lado, y las decisiones institucionales y la sociedad del Antiguo Régimen por otra parte, desajuste que por tanto llevaba a resaltar el papel revolucionario de la ideología que tenía como función volver a reacomodar las relaciones entre el campo discursivo-racional y el campo de la vida social. Tampoco puede proceder de un modelo sociográfico que fija previamente a los grupos sociales y luego les asigna características culturales. Consideramos, siguiendo al citado historiador francés, que las relaciones entre el mundo cultural y el social deben ser asumidas desde tres perspectivas: 1) analizando las formas de clasificación producidas por las diversas expresiones del mundo cultural (intelectual, mentalidad colectiva, conciencia de grupo) que permiten que los distintos sectores sociales originen construcciones diversas del mundo social. Se trata de esquemas que generan percepciones, clasificaciones y representaciones que cristalizan en instituciones sociales. 2) Estudiando las distintas expresiones prácticas de las identidades sociales que ponen en escena el status, el rango y la clase. Y 3) 
prestando atención a las formas como las instituciones objetivan y consagran esas representaciones y prácticas sociales diferenciadoras. ${ }^{91}$

En consonancia con ese modelo la atención debe concentrarse en el análisis tanto de la permanencia de tradiciones como también en el surgimiento de nuevas prácticas sociales, en el papel de las instituciones y de los discursos en la administración de esas prácticas y de los espacios en que se desarrollaron, determinando las influencias y los límites de los discursos y las instituciones en la reorganización de los sistemas de percepción y de ordenamiento del mundo social. Esto implica estudiar hasta dónde existió una sensibilidad que permitió recoger las transformaciones que se fueron operado en términos reales, como también los esfuerzos por introducir nuevas clasificaciones que podían o no podían machar aparejadas con esta realidad, y tenían efectos sobre las formas como el común de las gentes leía y se representaba el orden social, sus grupos y a sus actores individuales. De igual forma se debe analizar las discordancias que existen entre las ideologías que pretenden representar al mundo social y proponen su reorganización, y las prácticas que en su ejecución pueden conservar ya sea viejas ideologías o introducir nuevas distribuciones y clasificaciones. ${ }^{92}$

Con base en las anteriores consideraciones creemos conveniente que el estudio de las relaciones entre las formas "tradicionales" de leer, representarse y de actuar en el orden social del siglo XVIII (la gama de categorías socio-raciales y las prácticas sociales a ellas asociadas), y las novedades políticas introducidas desde 1770 en adelante, debe integrar el espacio de esos posibles cambios políticos con aquellos ámbitos de la vida social en que las personas y familias se relacionaban por fuera de los vínculos institucionales, pero que a su vez tenían consecuencias legales.

\footnotetext{
91 Roger Chartier, El mundo como representación. Historia cultural: entre práctica y representación, Barcelona, Ed. Gedisa, 1996, pp.56-57.

92 Roger Chartier, Espacio público, crítica y desacralización en el siglo XVIII. Los orígenes culturales de la Revolución Francesa, Barcelona, Ed. Gedisa, 1995, p.30.
} 


\section{Bibliografía}

\section{Fuentes primarias:}

Archivo General de Simancas (AGS), Dirección General de Rentas, $1^{\text {a }}$ Remesa, Catastro de Ensenada, Respuestas Generales, Libro n. ${ }^{0560,}$, Ciudad de Sevilla. 408 folios. http://goo.gl/6JtR6A.

Archivo General de Indias (AGI), Indiferente General; Mapas y Planos, Varios; Santo Domingo. Esta documentación puede consultarse em Madison Library de la University of Wisconsin. http://www.disc.wisc.edu/archive/padrones/index.html. (consulta: junio 3 de 2012).

Archivo General de la Nación (Colombia), Sección Colonia, fondo Censos RedimiblesCensos Varios Departamentos (AGN, SC, CR-CVD); fondo Curas y Obispos; fondo Milicias y Marina.

Archivo General de la Nación (Argentina), División Colonia; Sección Gobierno; Montevideo, leg.76; 1730-1804; Sala IX, 3-1-8. La transcripción de este padrón puede leerse en la web Pueblos y Números. Rio de La Plata 176o-186o. http://goo.gl/PwKTiK. (consulta: abril 16 de 2012).

Censo de Aranda, tomo I, Madrid, Real Academia de la Historia/Instituto Nacional de Estadística, 1991. (Edición facsimilar). http://goo.gl/Sjg39W. (consulta: junio 13 de 2012).

Censo español executado de Orden del Rey, comunicada por el Excelentísimo Señor Conde de Floridablanca, Primer Secretario del Estado y del Despacho, en el año de 1787, Madrid, Imprenta Real, 1787. http://goo.gl/nkJqIt. (consulta: junio 23 de 2012).

Jiménez, Orián y Pérez, Edgardo (comps.), Voces de esclavitud y libertad. Documentos y testimonios. Colombia 1701-1833, Popayán, Universidad del Cauca, 2013.

\section{Fuentes secundarias:}

Almeida Prado Bacellar, Carlos de, "Las listas nominativas de los habitantes de la capitanía de São Paulo, Brasil, bajo una mirada crítica”, en Dora Celton, Mónica Ghirardi y Adrián Carbonetti (coords.), Poblaciones históricas. Fuentes, métodos y líneas de investigación, Rio de Janeiro, Asociación Latinoamericana de la Población, 2009, pp.155-170. http://goo.gl/cenMLK. (consulta: abril 3 de 2012).

Andreazza, María, "El papel de los censos en la producción de las categorías sociales y es- 
paciales de las colonias americanas”, en Dora Celton, Mónica Ghirardi y Adrián Carbonetti (coords.), Poblaciones históricas. Fuentes, métodos y líneas de investigación, Rio de Janeiro, Asociación Latinoamericana de la Población, 2009, pp.117135. http://goo.gl/cenMLK. (consulta: abril 13 de 2012).

Anrup, Roland y Chaves, María E., "La 'plebe' en una sociedad de 'todos los colores'. La construcción de un imaginario social y político en la colonia tardía en Cartagena y Guayaquil”, en Caravelle n. ${ }^{\circ} 84$, Toulouse, Université de Toulouse, 2005, pp.93126.

Apolant, Juan A., "Padrones olvidados de Montevideo del siglo XVIII [II]. Padrón Aldecoa 1772-1773", en Boletín Histórico n. ${ }^{\circ} 106-107$, Montevideo, Ejército de Uruguay, 1965, pp.47-149. http://goo.gl/gwDzOa (consulta: abril 5 de 2012).

Araya, Alejandra, "Registrar a la plebe o el color de las castas: 'calidad', 'clase' y 'casta' en la matrícula de Alday (Chile, siglo XVIII)", en Alejandra Araya y Jaime Valenzuela (eds.), América colonial. Denominaciones, clasificaciones e identidades, Santiago de Chile, Pontificia Universidad Católica de Chile/Universidad de Chile/Red Internacional del Libro, 2010, pp.331-362.

Araya, Alejandra, "La Matrícula de Alday (1777-1778): imaginarios sociales y políticos en el siglo XVIII americano", en Grupo de Estudio de Historia de las Ciencias (eds.), Control social y objetivación: escrituras y tránsitos de las Ciencias en Chile, Santiago de Chile, Universidad de Chile, 2012, pp.15-33.

Ardit, M., Badenes, M. A. y Bernat, J. S., El pais Valencià en el cens d'Aranda (1768), Valencia, Universitat València, 2001.

Ares-Queija, Berta, “Mestizos, mulatos y zambaigos (virreinato del Perú siglo XVI)", en Berta Ares-Queija y Alessandro Stella (coords.), Negros, mulatos, zambaigos. Derroteros africanos en los mundos ibéricos, París/Sevilla, Centre National de la Recherche Scientifique/Escuela de Estudios Hispano Americanos, 2000, pp.75-88.

Ares-Queija, Berta, "Las categorías del mestizaje: desafíos a los constreñimientos de un modelo social en el Perú colonial temprano", en Histórica vol.XVIII, n. ${ }^{\circ}$, Lima, Pontificia Universidad Católica de Perú, 2004, pp.193-218.

Ares-Queija, Berta, “A los hijos de español y de india, o de indio y española, nos llaman mestizos... Construcciones identitarias en la América colonial española”. Conferencia en el Instituto de Estudos Avancados Transdisciplinares-Universidade Federal de Minas Gerais (sin fecha). http://goo.gl/ohx4Jo. (consulta: mayo 4 de 2012).

Barcia, María, La otra familia. Parientes, redes y descendencia de los esclavos en Cuba, Santiago de Cuba, Ed. Oriente, 2009. 
Bernand, Carmen, Negros, esclavos y libres en las ciudades hispanoamericanas, Madrid, Fundación Larramendi, 2000. http://goo.gl/XKQDed. (consulta: abril 29 de 2012).

Bernand, Carmen, "Mestizos, mulatos y ladinos en Hispanoamérica: un enfoque antropológico de un proceso histórico", en Miguel León Portilla (ed.), Motivos de la antropología americanista: Indagaciones en la diferencia, México D. F., Fondo de Cultura Económica, 2001, pp.105-133.

Boixadós, Roxana y Farberman, Judith, "Una aproximación a la diversidad étnica y social en Los Llanos riojanos del siglo XVIII", en Judith Farberman y Silvia Ratto (coords.), Historias mestizas en el Tucumán colonial y las pampas (siglos XVIIXVIII), Buenos Aires, Ed. Biblos, 2009, pp.79-114.

Bonil, Katherine, Gobierno y calidad en el orden social. Las categorías del mestizaje en la provincia de Mariquita en la segunda mitad del siglo XVIII, Bogotá, Universidad de los Andes, 2011.

Borrego, María, Cartagena de Indias. La andadura de una vida bajo la Colonia, Bogotá, El Áncora Eds., 2010.

Burn, Kathryn, "Desestabilizando la raza”, en Marisol de la Cadena (ed.), Formaciones de indianidad. Articulaciones raciales, mestizaje y nación en América Latina, Popayán, Ed. Envión, 2007, pp.35-54.

Cadena, Marisol de la, “¿son los mestizos híbridos? las políticas conceptuales de las identidades andinas", en Marisol de la Cadena (ed.), Formaciones de indianidad. Articulaciones raciales, mestizaje y nación en América Latina, Popayán, Ed. Envión, 2007, pp.83-116.

Cahill, David, "Colores cifrados: categorías raciales y étnicas en el virreinato peruano, 1532-1824”, en Nueva Síntesis n. ${ }^{\circ} 7-8$, Lima, Universidad de San Marcos, 2001, pp.29-58.

Calvo, Haroldo y Meisel, Adolfo (eds.), Cartagena de Indias en el siglo XVII, Cartagena, Banco de la República, 2007.

Carroll, Patrick J., "Estudio socio-demográfico de las personas de sangre negra en Jalapa, 1791", en Historia Mexicana vol.XXIII, n. ${ }^{\circ} 1$, México D. F., El Colegio de México, 1973, pp.111-125.

Carroll, Patrick J., "Perfiles demográficos y culturales esquemáticos en la comunidad de esclavos del centro de Veracruz dentro de un contexto interpretativo más amplio", en Signos Históricos vol.II, n. ${ }^{\circ}$ 4, México D. F., Universidad Autónoma Metropolitana-Iztapalapa, 2000, pp.55-86. 
Carroll, Patrick J., "El debate académico sobre los significados sociales entre clase y raza en el México del siglo XVIII”, en María E. Velásquez (coord.), Debates históricos contemporáneos: africanos y afrodescendientes en México y Centroamérica, México D. F., Centro de Estudios Mexicanos y Centroamericanos/Instituto Nacional de Antropología e Historia/Institut de Recherche pour le Développement/Universidad Nacional Autónoma de México, 2011, pp.111-142.

Castañeda, Carmen y Gómez, Laura, "La población de Guadalajara de acuerdo con el padrón militar de 1791 y el censo de la intendencia de 1793”, en Historias n. ${ }^{\circ} 76$, México D. F., Instituto Nacional de Antropología e Historia, 2000, pp.45-66. http://goo.gl/d6KjRp. (consulta: mayo 17 de 2012).

Castillo, Norma, Cholula. Sociedad mestiza en ciudad india. Un estudio sobre las causas económicas, sociales y demográficas del mestizaje en una provincia novohispana, México D. F., Universidad Autónoma Metropolitana-Iztapalapa/Plaza y Valdés, 2001.

Castillo, Norma, "Informaciones y probanzas de limpieza de sangre. Teoría y realidad frente a la movilidad social de la población novohispana producida por el mestizaje", en Nikolaus Böttcher, Bernd Hausberger y Max Hering Torres (eds.), El peso de la sangre. Limpios, mestizos y nobles en el Mundo Hispánico, México D. F., El Colegio de México, 2011, pp.219-250.

Castro, Hugo, Primer censo de la población de la Nueva España, 179o. Censo de Revillagigedo "un censo condenado", México D. F., Dirección General de Estadísticas, 1777. http://goo.gl/VjWWd5. (consulta: junio 2 de 2012).

Castro Leiva, Luis, "Memorial de la modernidad: lenguaje de la razón e invención del individuo", en Antonio Annino, François-Xavier Guerra y Luis Castro Leiva (dirs.), De los Imperios a las Naciones: Iberoamérica, Zaragoza, Ibercaja, 1994, pp.129-165.

Cobo, Juan, Mestizos heraldos de Dios. La ordenación de sacerdotes descendientes de españoles e indígenas en el Nuevo Reino de Granada y la racialización de la diferencia 1573-159O, Bogotá, Instituto Colombiano de Antropología e Historia, 2012.

Coello, Alexandre, "De mestizos y criollos en la Compañía de Jesús (Perú, siglos XVI-XVII)”, en Revista de Indias vol.LXVIII, n. ${ }^{\circ} 243$, Madrid, Consejo Superior de Investigaciones Científicas, 2008, pp.37-66.

Coello, Alexandre y Numhauser, Paulina, "Introducción: Criollismo y mestizaje en el mundo andino (siglos XVI-XIX)", en Illis $i$ Imperis n. ${ }^{\circ} 14$, Barcelona, Universitat Pompeu Fabra, 2012, pp.13-48.

Colmenares, Germán, Encomienda y población en la provincia de Pamplona, 1549-1650, Bogotá, Universidad de los Andes, 1969. 
Colmenares, Germán, La provincia de Tunja en el Nuevo Reino de Granada, Bogotá, Universidad de los Andes, 1970.

Colmenares, Germán, Popayán una sociedad esclavista, 1680-18oo, Medellín, La Carreta Eds., 1979.

Commons, Áurea, "La población de Nueva España en 1790”, en Tempus n. ${ }^{3}$, México, D. F., Universidad Nacional Autónoma de México, 1995, pp.7-112. http://goo.gl/I837CZ. (Consulta. Junio 17 de 2012).

Conde, Jorge, Espacio, sociedad y conflictos en la provincia de Cartagena 1740-1815, Barranquilla, Universidad del Atlántico, 1999.

Conde, Jorge, Buscando la nación. Ciudadanía, clase y tensión racial en el Caribe colombiano, 1821-1855, Medellín, Universidad del Atlántico/La Carreta Eds., 2009.

Conde, Jorge, "Los xefes de los pardos: la consolidación de un sector social intermedio durante la independencia de Cartagena de Indias", en Historia y Sociedad n. ${ }^{\circ} 23$, Medellín, Universidad Nacional, 2012, pp.147-173.

Conde, Jorge y Monsalvo, Edwin, "Las clases del pueblo en ebullición. Pardos y mulatos en la independencia de Cartagena 1809-1815”, en Amauta n. ${ }^{\circ} 19$, Barranquilla, Universidad del Atlántico, 2012, pp.33-49.

Contreras, Carlos y Pardo, Claudia, "La cuenta de feligreses en Puebla de los Ángeles en 1777. Población y estructura racial”, en Carlos Contreras y Claudia Pardo (coords.), El Obispado de Puebla. Españoles, indios, mestizos y castas en tiempos del virrey Bucareli, 1777, Puebla, Benemérita Universidad de Puebla/Instituto de Ciencias Sociales y Humanidades “Alfonso Vélez Pliego", 2007, pp.29-71.

Cook, Sherburne F. y Borah, Woodrow, Ensayos sobre la historia de la población. México y el Caribe I, vol.1, México D. F., Siglo XXI, 1998.

Curtis, Katherine J. and Scarano, Francisco, "Puerto Rico's population padrones, 17791802", in Latin American Research Review vol.46, n. ${ }^{\circ}$ 2, Pittsburgh, Latin American Studies Association, 2011, pp.200-213. http://goo.gl/qE7qFx. (consulta: mayo 17 de 2012).

Chartier, Roger, Espacio público, crítica y desacralización en el siglo XVIII. Los orígenes culturales de la Revolución Francesa, Barcelona, Ed. Gedisa, 1995.

Chartier, Roger, El mundo como representación. Historia cultural: entre práctica y representación, Barcelona, Ed. Gedisa, 1996.

Chaves, María E., “La creación del ‘otro’ colonial. Apuntes para un estudio de la diferencia 
en el proceso de la conquista americana y de la esclavización de los africanos”, en María E. Chaves (ed.), Genealogías de la diferencia. Tecnologías de la salvación y representación de los africanos esclavizados en Iberoamérica colonial, Bogotá, Universidad Javeriana, 2009, pp.178-243.

Deans-Smith, Susan, "Creating the colonial subject. Casta paintings, collectors, and critics in Eighteenth-Century Mexico and Spain", in Colonial Latin American Review vol.14, n. ${ }^{\circ}$, Albuquerque, University of New México, 2005, pp.169-204. http://goo.gl/1015te. (consulta: abril 15 de 2012).

Ebert, Anne, "la representación de las américas coloniales en los cuadros de castas", en Scientia vol.x, n. ${ }^{\circ}$ 10, Lima, Universidad Ricardo Palma, 2008, pp.139-152. http://goo.gl/CJYqJ4. (consulta: junio 5 de 2012).

Escobar, Antonio, "La estructura socioeconómica de las Huastecas en el siglo XVIII. El censo militar de 1791", en La Palabra y el Hombre n. ${ }^{\circ}$ 96, Veracruz, Universidad Veracruzana, 1995, pp.5-36.

Estenssoro, Juan Carlos, "Los colores de la plebe. Razón y mestizaje en el Perú colonial”, en Los cuadros de mestizaje del Virrey Amat. La representación etnográfica en el Perú colonial, Lima, Museo de Arte Lima, 2000, pp.67-107.

Eugenio, María Ángeles, Tributo y trabajo del indio en Nueva Granada (de Jiménez de Quesada a Sande), Madrid, Escuela de Estudios Hispano Americanos/Consejo Superior de Investigaciones Científicas, 1977.

Ferrer, Ada, “Cuba en la sombra de Haití: Noticias, sociedad y esclavitud”, en María González, Consuelo Naranjo, Ada Ferrer y José Opatrný, El rumor de Haití en Cuba: temor, raza y rebeldía, 1789-1844, Sevilla, Consejo Superior de Investigaciones Científicas, 2004, pp.179-231.

Francis, Michael, "Población, enfermedad y cambio demográfico, 1537-1636. Demografía histórica de Tunja: Una mirada crítica”, en Fronteras de la Historia n. ${ }^{\circ} 7$, Bogotá, Instituto Colombiano de Antropología e Historia, 2002, pp.13-76.

Friede, Juan, "Algunas consideraciones sobre la evolución demográfica en la Provincia de Tunja”, en Anuario Colombiano de Historia Social y de la Cultura n. ${ }^{\circ}$, Bogotá, Universidad Nacional, 1965, pp.5-19.

Garavaglia, Juan C. y Grosso, Juan C., "Identidad, identidades: una visión desde la América hispana - siglos XVIII-XIX”, en Quaderns n. ${ }^{\circ} 25$, Barcelona, Universidad Autónoma de Barcelona, 2009, pp.19-45.

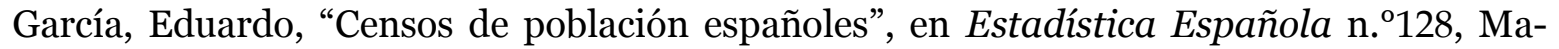
drid, Instituto Nacional de Estadística, 1991, pp.441-500. 
García de León, Antonio, Tierra adentro, mar en fuera. El puerto de Veracruz y su litoral a Sotavento, 1519-1821, México D. F., Fondo de Cultura Económica/Gobierno del Estado de Veracruz/Universidad Veracruzana, 2011.

Garrido, Margarita, Reclamos y representaciones. Variaciones sobre la política en el Nuevo Reino de Granada 1770-1815, Bogotá, Banco de la República, 1992.

Garrido, Margarita, "Libres de todos los colores en Nueva Granada. Identidad y obediencia antes de la Independencia”, en Nils Jacobsen y Cristóbal Aljovín (coords.), Cultura política en los Andes, Lima, Universidad Nacional Mayor de San Marcos/Instituto Francés de Estudios Andinos, 2007, pp.245-266.

Garrido, Margarita, "Honor, reconocimiento, libertad y desacato: sociedad e individuo desde un pasado cercano", en Luz Arango, Gabriel Restrepo y Carlos Jaramillo (eds.), Cultura, política y modernidad, Bogotá, Universidad Nacional, 1998, pp.99121.

Gómez, Carmen, "La población de Cartagena de Indias a principios del siglo XVIII", en Temas Americanistas n. ${ }^{\circ}$ 2, Sevilla, Universidad de Sevilla, 1983, pp.43-52.

Gómez, Fernando, “Los censos en Colombia antes de 1905”, en Miguel Urrutia y Mario Arrubla (comps.), Compendio de estadística histórica de Colombia, Bogotá, Universidad Nacional, 1970, pp.9-30.

Gonzalbo, Pilar, La familia y el nuevo orden colonial, México D. F., El Colegio de México, 1998.

Gonzalbo, Pilar, "La vida familiar y las móviles fronteras sociales en el siglo XVIII novohispano”, en Montalbán n. ${ }^{\circ}$ 34, Caracas, Universidad Andrés Bello, 2001, pp.201-218.

Good, Catharine, "Reflexiones sobre la raza y el racismo; el problema de los negros, los indios, el nacionalismo y la modernidad", en Dimensión Antropológica n. ${ }^{\circ} 14$, México D. F., Instituto Nacional de Antropología e Historia, 1999. http://goo.gl/6gLMI4. (consulta: junio 17 de 2012).

Guarisco, Claudia, "El reformismo borbónico y la participación política de indios y estado llano en el Valle de México" en Jahrbuch für Geschichte Lateinamerikas nº 40, Viena, Universität Graz, 2003, pp.97-121.

Helg, Aline, Libertad e igualdad en el Caribe colombiano 1770-1835, Medellín, Eafit/Banco de la República, 2011.

Hering Torres, Max, “Color, pureza, raza: la calidad de los sujetos coloniales”, en Heraclio Bonilla (ed.), La cuestión colonial, Bogotá, Ed. Norma, 2011, pp.451-469; "La limpieza de sangre en España: un modelo de interpretación”, en Nikolaus Böttcher, 
Bernd Hausberger y Max Hering Torres (eds.), El peso de la sangre. Limpios, mestizos y nobles en el Mundo Hispánico, México D. F., El Colegio de México, 2011, pp.23-54.

Hernández, Juan, "La realización del censo de Floridablanca en el corregimiento de Murcia”, en Studia Historica: Historia Moderna n. ${ }^{\circ}$, Salamanca, Universidad de Salamanca, 1987, pp.285-297.

Herrera, Marta, “'Chimilas' y 'españoles': el manejo político de los estereotipos raciales en la sociedad neogranadina del siglo XVIII”, en Memoria y Sociedad vol.7, n. ${ }^{\circ} 13$, Bogotá, Universidad Javeriana, 2002, pp.5-24.

Herrera, Marta, "Libres de todos los colores el ordenamiento social en las llanuras del Caribe, siglo XVIII", en Alberto Abello (comp.), El Caribe en la nación colombiana (Memorias), Bogotá, Museo Nacional de Colombia/Observatorio del Caribe Colombiano, 2006, pp.248-267.

Herrera, Marta, "El arrochelamiento: nominar para criminalizar”, en El Taller de la Historia n. ${ }^{\circ}$, Cartagena, Universidad de Cartagena, 2010, pp.11-46.

Herrera, Marta, "El poblamiento en el siglo XVI y principios del XVII. Contrastes entre el Caribe y el interior andino", en Haroldo Calvo y Adolfo Meisel (eds.), Cartagena de Indias en el siglo XVI, Cartagena, Banco de la República, 2010, pp.203-237.

Herzog, Tamar, Vecinos y extranjeros. Hacerse español en la Edad Moderna, Madrid, Alianza Editorial, 2006.

Jaramillo Uribe, Jaime, "La población indígena de Colombia en el momento de la conquista y sus transformaciones posteriores", en Anuario Colombiano de Historia Social y de la Cultura n. ${ }^{\circ}$ 2, Bogotá, Universidad Nacional, 1964, pp.239-293.

Juárez, María, Estructura poblacional de Durango en 1778, México D. F., trabajo de grado licenciada en Historia-Universidad Autónoma Metropolitana Iztapalapa, 1998. http://goo.gl/BqOVXo. (consulta: mayo 30 de 2012).

Katzew, Ilona, La pintura de castas. Representaciones raciales en México del siglo XVIII, Madrid/México D. F., Conaculta/Turner, 2004. http://goo.gl/UBp2iV. (consulta: mayo 21 de 2012).

Klein, Herbert S. y Vinson III, Ben, La esclavitud en América Latina y el Caribe, México D. F., El Colegio de México, 2013.

Lempérière, Annick, "La recepción negativa de una grande idea: el absolutismo en Nueva España en la segunda mitad del siglo XVIII”, en Mónica Quijada y Juan Bustamante (dirs.), Elites intelectuales y modelos colectivos. Mundo ibérico (siglo XVI-XIX), 
Madrid, Consejo Superior de Investigaciones Científicas, 2002, pp.199-218.

López Beltrán, Carlos, "Sangre y temperamento. Pureza y mestizajes en las sociedades de castas americanas”, en Frida Gorbach y Carlos López-Beltrán (eds.), Saberes locales: ensayos sobre historia de la ciencia en América Latina, Zamora, El Colegio de Michoacán, 2008, pp.289-342.

Marchena, Juan, "Su Majestad quiere saber. Información oficial y reformismo borbónico en la América de la Ilustración” en Diana Soto, Miguel Puig, Martina Bender y María González (eds.), Recepción y difusión de textos ilustrados. Intercambio científico entre Europa y América en la Ilustración, Madrid, Rudecolombia/Colciencias/Universidad Pedagógica y Tecnológica de Colombia/Universidad de León/Doce Calles, 2003, pp.151-185.

Martínez, Armando, "Arrabal, prejuicio moral y demanda de instrucción: elementos para comprender el estatus de los caballeros pardos en la transición a la sociedad republicana”, en Historia Caribe vol.vi, n. ${ }^{\circ} 19$, Barranquilla, Universidad del Atlántico, 2011, pp.13-41.

Marzahl, Peter, Una ciudad en el Imperio. El gobierno, la política y la sociedad de Popayán en el siglo XVII, Popayán, Universidad del Cauca, 2013.

Mayer, Leticia, "Los censos novohispanos a finales del siglo XVIII". Ponencia leída en el Congreso de la Latin American Studies Association, Rio de Janeiro, junio de 2009. http://goo.gl/oZ2ojt. (consulta: junio 7 de 2012).

Mentz, Brígida von, "La elaboración de matrículas poblacionales y el contexto social. Análisis de dos tradiciones estatales y de la relación entre registradores y registrados en la región de Cuernavaca, 1540-1671”, en América Molina y David Navarrete (coords.), Problemas demográficos vistos desde la historia, Zamora, El Colegio de Michoacán/Centro de Investigaciones y Estudios Superiores en Antropología Social/Conacyt, 2006, pp.29-66.

Meriño, María y Perera, Aisnara, Familias, agregados y esclavos. Los padrones de vecinos de Santiago de Cuba (1778-1868), Santiago de Cuba, Eds. Oriente, 2011.

Mingarro, Maríangeles, Tributo y familia en la Nueva Granada. La provincia de Tunja en los siglos XVII y XVIII, Valencia, Universitat Jaume I, 2004.

Miño, Manuel, "Para la historia social. Tablas de edad, estado marital y grupos raciales de la población de la Ciudad de México, 1790 (13 cuarteles)”, en Historia Mexicana vol.LVII, n. ${ }^{\circ}$ 3, México D. F., El Colegio de México, 2008, pp.911-944.

Morelli, Federica, "La redefinición de las relaciones imperiales: en torno a la relación reformas dieciochescas/independencia en América", en Nuevo Mundo Mundos Nue- 
vos 2008. http://goo.gl/oSZAZF. (consulta: junio 24 de 2012).

Morelli, Federica, "La recepción negativa de una grande idea: el absolutismo en Nueva España en la segunda mitad del siglo XVIII", en Mónica Quijada y Juan Bustamante (dirs.), Elites intelectuales y modelos colectivos. Mundo ibérico (siglo XVI-XIX), Madrid, Consejo Superior de Investigaciones Científicas, 2002, pp.199-218.

Múnera, Alfonso, Fronteras imaginadas, Bogotá, Planeta, 2005.

Navarrete, María C., Génesis y desarrollo de la esclavitud en Colombia siglos XVI y XVII, Cali, Universidad del Valle, 2012.

Olivero, Sandra, Sociedad y economía en San Isidro colonial. Buenos Aires, siglo XVIII, Sevilla, Universidad de Sevilla, 2006.

Pérez, Vicente, "La estadística demográfica en el gobierno de la España ilustrada: recuerdo y elogio del Censo de Floridablanca", en Índice n. ${ }^{\circ} 43$, Madrid, Instituto Nacional de Estadística/Universidad Autónoma de Madrid, 2010, pp.8-17.

Pérez Toledo, Sonia, Población y estructura social de la Ciudad de México, 179o-1842, México D. F., Universidad Autónoma Metropolitana/Conacyt, 2004.

Pietschmann, Horst, "Protoliberalismo, reformas borbónicas y revolución: la Nueva España en el último tercio del siglo XVIII”, en Josefina Zoraida Vázquez (dir.), Interpretaciones del siglo XVIII mexicano. El impacto de las reformas borbónicas, México D. F., Nueva Imagen, 1992, pp.27-58.

Poloni-Simard, Jean, El mosaico indígena: movilidad, estratificación social y mestizaje en el en el corregimiento de Cuenca (Ecuador) del siglo XVI al XVIII, Quito, AbyaYala/Instituto Francés de Estudios Andinos, 2006.

Rappaport, Joanne, “Quién es mestizo? Descifrando la mezcla racial en el Nuevo Reino de Granada siglos XVI y XVII”, en Varia História vol.25, n. ${ }^{\circ} 41$, Belo Horizonte, Universidades de Minas Gerais, 2009, pp.43-60.

Rappaport, Joanne, “'Asi lo paresçe por su aspeto’: fisiognomía y construcción de la diferencia en la Bogotá colonial”, en Tabula Rasa n. ${ }^{\circ}$, Bogotá, Universidad Central, 2012, pp.13-42.

Rappaport, Joanne, “'Asi lo paresçe por su aspeto’: fisiognomía y construcción de la diferencia en la Bogotá colonial”, en Tábula Rasa n. ${ }^{\circ}$, Bogotá, Universidad Central, 2012, pp.13-42.

Rappaport, Joanne, "Buena sangre y hábitos españoles: repensando a Alonso de Silva y Diego de Torres", en Anuario Colombiano de Historia Social y de la Cultura 
vol.39, n. ${ }^{\circ}$, Bogotá, Universidad Nacional, 2012, pp.19-48.

Rappaport, Joanne, "El mestizo que desaparece: El género en la construcción de redes sociales entre mestizos de élite en Santafé de Bogotá, siglos XVI y XVII", en Juan Escobar, Sarah de Mojica y Adolfo Maya (eds.), Celebraciones y crisis: Procesos independentistas en Iberoamérica y la Nueva Granada, Bogotá, Universidad Javeriana, 2012, pp.365-386.

Reid Andrews, George Afrolatinoamérica 1800-20oo, Madrid/Frankfurt, Iberoamericana/Vervuert, 2007.

Restrepo, Eduardo, "El negro en un pensamiento colonial de principios del siglo XVII: diferencia, jerarquía y sujeción sin racialización”, en María E. Chaves (ed.), Genealogías de la diferencia. Tecnologías de la salvación y representación de los africanos esclavizados en Iberoamérica colonial, Bogotá, Universidad Javeriana, 2009, pp.119-176.

Retratos de nuestra identidad: Los censos de población en Chile y su evolución histórica hacia el Bicentenario, Santiago de Chile, Instituto Nacional de Estadística, 2009. http://goo.gl/EtWjz3. (consulta: junio 19 de 2012).

Rodríguez, Ileana y Martínez, Josebe (eds.), Estudios trasatlánticos postcoloniales. II. Mitos, archivo, disciplina: cartografías culturales, Barcelona/México D. F., Anthropos/Universidad Autónoma Metropolitana, 2010.

Rodríguez, Lorena, "Repensando las clasificaciones socio-étnicas del siglo XVIII. Indios, mestizos y españoles al sur del valle Calchaquí (Argentina)", en Fronteras de la Historia vol.13, n. $^{\circ}$, Bogotá, Instituto Colombiano de Antropología e Historia, 2008, pp.305-326.

Romero, Diego, Poblamiento y sociedad en el Pacífico colombiano siglos XVI al XVIII, Cali, Universidad del Valle, 1995.

Romero de Tejada, Pilar, "Los cuadros de mestizaje del Virrey Amat", en Frutas y castas Ilustradas, Madrid, Museo Nacional de Antropología/Ministerio de Educación, Cultura y Deporte, 2004, pp.11-23.

Ruiz, Julián, Fuentes para la demografía histórica de Nueva Granada, Sevilla, Escuela de Estudios Hispano Americanos, 1972.

Ruiz, Julián, Encomienda y mita en Nueva Granada en el siglo XVII, Sevilla, Escuela de Estudios Hispano Americanos, 1975.

Ruiz, Julián, Los indios de Cartagena bajo la administración española en el siglo XVII, Bogotá, Archivo General de la Nación, 1996. 
Ruiz, Julián, "Gobierno, comercio y sociedad en Cartagena de Indias en el siglo XVII", en Adolfo Meisel y Haroldo Calvo (eds.), Cartagena de Indias en el siglo XVII, Cartagena, Banco de la República, 2007, pp.354-376.

Saether, Steinar, Identidades e independencia en Santa Marta y Riohacha, 1750-1850, Bogotá, Instituto Colombiano de Antropología e Historia, 2005.

Saether, Steinar, "Counting indians: census categories in late colonial and early republican Spanish America”, in Per Axelsson and Peter Sköld (eds.), Indigenous peoples and demography. The complex relation between identity and statistics, Oxford, Berghahn Books, 2011, pp.55-71.

Sánchez, Ernest, Padrón del arzobispado de México 1777, México D. F., Archivo General de la Nación, 2003.

Sánchez, Ernest, "La población de la Ciudad de México en 1777”, en Secuencia n. ${ }^{\circ 60}$, México D. F., Instituto Mora, 2004.

Sánchez, Ernest, "El nuevo orden parroquial de Ciudad de México: población, etnia y territorio (1768-1777)", en Estudios de Historia Novohispana n. ${ }^{\circ} 30$, México D. F., Universidad Nacional Autónoma de México, 2004, pp.63-92.

Santos, Jocelio Teles dos, "De pardos disfrazados a blancos poco claro: clasificaciones raciales en el Brasil de los siglos XVIII y XIX”, en El Taller de la Historia vol.5, n. ${ }^{\circ}$, Cartagena, Universidad de Cartagena, 2013, pp.79-103.

Schwaller, Robert, “'Mulata, hija de negro y india': Afro-Indigenous Mulatos in Early Colonial Mexico", in Journal of Social History vol.44, n. ${ }^{\circ}$, Oxford, Oxford University Press, 2011, pp.889-914. http://goo.gl/uLQkHR. (consulta: Julio 2 de 2012).

Schwartz, Stuart, "Spaniards, 'pardos', and the missing mestizos: identities and racial categories in the early hispanic Caribbean", in New West Indian Guide vol.71, n. ${ }^{\circ} 1-2$, Amsterdam, Royal Netherlands Institute of Southeast Asian and Caribbean Studies, 1997, pp.5-19. http://goo.gl/4Gu6Sp. (consulta: julio 15 de 2012).

Silva, Luiz Geraldo, "Negros de Cartagena y Pernambuco en la era de las revoluciones atlánticas: trayectorias y estructuras (1750-1840)", en Anuario Colombiano de Historia Social y de la Cultura vol.40, n. ${ }^{\circ}$ 2, Bogotá, Universidad Nacional, 2013, pp.211-240.

Solano, Sergio Paolo, "Representaciones socio-raciales en el Nuevo Reino de Granada del siglo XVIII: censo de 1777, listados de milicianos y juicios por ofensas al status y al honor", en José Polo y Rafael Acevedo (eds.), Poder y formas de sociabilidad en Colombia, 1750-1850, Medellín, Universidad de Cartagena/La Carreta Eds., 2014, (en prensa). 
Solano, Sergio Paolo, "Poder, escritura y representaciones sociales. Configuración socioracial del Nuevo Reino de Granada, siglo XVIII", en Memorias vol.11, n. ${ }^{\circ} 23$, Barranquilla, Universidad del Norte, 2014 (en prensa).

Souto Mantecón, Matilde, "Composición familiar y estructura ocupacional de la población de origen español en Jalapa de la Feria (1791)", en Estudios de Historia de Nueva España n. ${ }^{\circ}$ 27, México D. F., Universidad Nacional Autónoma de México, 2002, pp.91-122.

Stolcke, Verena, "Los mestizos no nacen sino que se hacen", en Verena Stolcke y Alexandre Coello (comp.), Identidades ambivalentes en América Latina (siglos XVI-XXI), Barcelona, Eds. Bellaterra, 2008, pp.14-51.

Stolcke, Verena, “A propósito de fronteras y mestizajes”, en Monserrat Ventura (ed.), Fronteras de mestizajes. Sistemas de clasificación social en Europa, América y África, Barcelona, Universidad Autónoma de Barcelona, 2010, pp.19-29.

Tovar, Hermes, "Estado actual de los estudios de demografía histórica en Colombia", en Anuario Colombiano de Historia Social y de la Cultura n. ${ }^{\circ} 5$, Bogotá, Universidad Nacional, 1970, pp.65-140.

Tovar, Hermes, La estación del miedo o la desolación dispersa. El Caribe colombiano en el siglo XVI, Bogotá, Ariel, 1997.

Tovar, Hermes, Tovar, Camilo y Tovar, Jorge, Convocatoria al poder del número. Censos y estadísticas de la Nueva Granada (1750-1830), Bogotá, Archivo General de la Nación, 1995.

Twinam, Ann, "Pedro de Ayarza. The purchase of whiteness", in Kenneth Andrien (ed.), The human tradition in Colonial Latin America, Lanham, Rowman \& Littlefield, 2002, pp.194-210.

Twinam, Ann, "The etiology of racial passing: Constructions of informal and official "Whiteness" in Colonial Spanish America", in John Smolenski and Thomas Humphrey (eds.), New World Orders, Violence, Sanction, and Authority in the Early Modern Americas, Philadelphia, University of Pennsylvania Press, 2005, pp.249-272.

Twinam, Ann, Vidas públicas, secretos privados. Género, honor, sexualidad e ilegitimidad en la Hispanoamérica colonial, Buenos Aires, Fondo de Cultura Económica, 2009.

Twinam, Ann, Repensando las reformas sociales de los borbones en las colonias, siglo XVIII", en El Taller de la Historia vol.5, n. ${ }^{\circ} 5$, Cartagena, Universidad de Cartagena, 2013, pp.5-32. 
Twinam, Ann, “American Defects:" Pardos, mulatos and the quest for whiteness in the Spanish Indies, Stanford, Stanford University Press, 2014, (en prensa).

Undurraga, Verónica, "Españoles oscuros y mulatos blancos: identidades múltiples y disfraces del color en el ocaso de la Colonia chilena. 1778-1820", en Rafael Gaune y Martín Lara (coords.), Historias de racismo y discriminación en Chile, Santiago, Uq-Bar, 2010, pp.345-373.

Velásquez, María E., "Africanos y afrodescendientes en México: premisas que obstaculizan entender su pasado y presente”, en Cuicuilco vol.18, n. ${ }^{\circ} 51$, México D. F., Escuela Nacional de Antropología e Historia, 2011, pp.11-22.

Velásquez, María E., “Introducción”, en María E. Velásquez (coord.), Debates históricos contemporáneos: africanos y afrodescendientes en México y Centroamérica, México D. F., Centro de Estudios Mexicanos y Centroamericanos/Instituto Nacional de Antropología e Historia/Institut de Recherche pour le Développement/Universidad Nacional Autónoma de México, 2011, pp.13-31.

Vinson III, Ben, "Estudiando las razas desde la periferia: las castas olvidadas del sistema colonial mexicano (lobos, moriscos, coyotes, moros y chinos)", en Juan M. de la Serna (ed.), Pautas de convivencia étnica en la América Latina colonial, México D. F., Universidad Nacional Autónoma de México, 2005, pp.247-307.

Vinson III, Ben, "Moriscos y lobos en la Nueva España”, en María E. Velásquez (coord.), Debates históricos contemporáneos: africanos y afrodescendientes en México y Centroamérica, México D. F., Centro de Estudios Mexicanos y Centroamericanos/Instituto Nacional de Antropología e Historia/Institut de Recherche pour le Développement/Universidad Nacional Autónoma de México, 2011, pp.159-178.

Wu, Celia, "La población de la ciudad de Querétaro en 1791", en Historias n. ${ }^{20}$, México D. F., Instituto Nacional de Antropología e Historia, 1988, pp.67-88. http://goo.gl/dGzqCI. (consulta: junio 30 de 2012).

Zambrano, Marta, Trabajadores, villanos y amantes: encuentros entre indígenas y españoles en la ciudad letrada. Santa Fe de Bogotá (1550-1650), Bogotá, Instituto Colombiano de Antropología e Historia, 2008.

Zambrano, Marta, "Ilegitimidad, cruce de sangre y desigualdad: dilemas del porvenir en Santa Fe colonial", en Nikolaus Böttcher, Bernd Hausberger y Max Hering Torres (eds.), El peso de la sangre. Limpios, mestizos y nobles en el Mundo Hispánico, México D. F., El Colegio de México, 2011, pp.251-281. 